Int. J. Dev. Biol. 61: 505-517 (2017)

doi: $10.1387 / \mathrm{ijdb} .170044 \mathrm{jf}$

\title{
Planar polarity of the extraembryonic epithelia in the preimplantation porcine conceptus
}

\author{
JACQUES-EDMOND FLECHON* \\ UMR Biologie du Développement et Reproduction, INRA, Jouy-en-Josas, France
}

\begin{abstract}
The present review deals with the trophoblast structure during the free intrauterine life of the pig blastocyst. The term trophoblast is used here to describe the association of the first extraembryonic cell layers, the trophectoderm and the primitive endoderm that are polarized epithelia, a fact established by ultrastructural and immunocytochemical data. The aim of this synthesis is to gather the relative works dispersed in the litterature and to explain the implication of the planar polarity of these cell layers on their developmental fate and roles. These epithelia are intricately dependent on each other for the maintenance of their differentiated state and continuity. The modalities of their spectacular expansion can be explained in part by biomechanical concepts.
\end{abstract}

KEY WORDS: pig trophoblast, cytoskeleton, cell junction, basal lamina, mechanobiology

\section{Introduction}

This review is particularly focussed on the morphology and roles of the cytoskeleton, related membrane junctions and basal lamina (BL) of the pig initial extraembryonic cell layers, the trophectoderm ( $\mathrm{T})$ and primitive endoderm (E), also called hypoblast. The differentiation of the embryonic ectoderm was previously described (Fléchon et al., 2004a). We will limit our scope to the period of post-hatching free intrauterine life of the conceptus (blastocyst's embryonic disc and elongated extraembryonic appendage). This is the time during which occurs an explosive and asynchronous expansion of the blastocysts, and also a period of high mortality rate (review by Geisert and Schmitt, 2015). The T surface changes relative to implantation will not be examined.

In ancestral types of eutherians, a trophectodem-like epithelium surrounding the blastocoele gives rise to the initial cells of embryonic ectoderm and of primitive $E$ (review by Sheng, 2015). In pig, the extraembryonic cell layers, $\mathrm{T}$ and $\mathrm{E}$, take their respective origin from the periphery of the morula and from the inner cell mass; they immediately appear as monostratified and polarized epithelia. The molecular basis of the T cell type maintenance in blastocysts was reviewed by Pfeffer and Pearton (2012). The authors point out that the commitment of the T cells is late in bovine (an archaic inheritance?). This may also be true for the pig where Oct-4, a marker of pluripotency, is expressed in the T of early blastocysts (Kirchhof et al., 2000; Kuijk et al., 2008) and incidentally is necessary for its differentiation (Emura et al., 2016).
Some epithelial markers of the T cells were studied in bovine blastocysts obtained in vitro (Shehu etal., 1996) and in vivo (Barcroft et al., 1998), however no systematic analysis on the subject, and moreover on the $\mathrm{E}$, was reported in pig until now. It is primordial to understand how the cell layer continuity is maintained particularly in rapidly proliferating epithelia (Herszterg et al., 2014), like $\mathrm{T}$ and $\mathrm{E}$. We will analyse for both cell types the elements of the cytoskeleton, successively the intermediate filaments (IFs) made of cytokeratins, usefull to characterize epithelia, the microtubules (MTs) made of tubulins and the microfilaments (MFs) of F-actin, the two latter playing roles in cell division, cell shape and intracellular transport, as described below. MFs or stress fibers are the contracile elements of the cytoskeleton, whereas IFs or tonofilaments are their more static counterpart. In epithelial cells, they are both bound to specific junctions and the resulting cell frame secures the cohesion of the epithelium which is moreover bound to the underlying BL. It is also important to keep in mind that each of these extaembryonic cell layers constitute a physiological entity, united by gap junctions (Fléchon, 2004b).

After a review of the morphology and roles of the T and E, lacking for the pig blastocyst, but available for the bovine e.g., (Betteridge and Fléchon, 1988), the basic knowledge will be examined on the different constituents of the cytoskeleton and associated protein

Abbreviations used in this paper: BL, basal lamina; E, endoderm; ECM, extracellular matrix; IF, intermediate filament; MF, microfilament; MT, microtubule; PM, plasma membrane; $\mathrm{T}$, trophectoderm.

*Address correspondence to: Jacques-Edmond Flechon. UMR Biologie du Développement et Reproduction, INRA, 78352 Jouy-en-Josas, France.
E-mail: jb.flechon@ orange.fr (iD) http://orcid.org/0000-0001-5547-6709

Supplementary Material (seven figures) for this paper is available at: http://dx.doi.org/10.1387/ijdb.170044jf

Submitted: 23 February, 2017; Accepted: 19 June, 2017.

ISSN: Online 1696-3547, Print 0214-6282

(c) 2017 UPV/EHU Press

Printed in Spain 
specific to simple epithelia. For more informations, see specialized reviews. Parallels will be established with the results obtained on pig $\mathrm{T}$ and $\mathrm{E}$ cell layers. Part of the following data published in research articles will be referenced, and part, unpublished, (presented in meetings by ourself), will be given without references. All the techniques used to obtain these results (chemicals, specific stains and antibodies) were described in cited articles. Most of the reported fluorescence microscope observations were made without a confocal microscope, as it is possible to focus throughout the flat trophoblast in whole mounts. The animals used for the reported studies were Large White gilts, except when indicated and the age of the embryos is given in days of gestation (days post-coitum: p. c.).

\section{Morphology of the free blastocyst}

The initial morphology of the pig blastocyst is similar to that of most other eutherian mammals. The relative distribution of cell layers at the embryonic pole, before and after mesoderm appearence, is shown in Fig. 5-8 of Barends et al.,1989). As described below, the next step is an elongation giving rise to a tubular conceptus.

\section{Trophectoderm development}

The hatched pig blastocyst is spherical and measures $8-10 \mathrm{~mm}$ in diameter on day 10 p. c. In the following step of expansion, it becomes ovoid (around $1 \times 2 \mathrm{~cm}$, at day 10-12) during a very rapid phase of elongation (a few hours); it takes a tubular form (10-40 $\mathrm{mm}$ long at day 12) and finally becomes filamentous, with slightly bulbous ends, reaching up to one metre at the start of implantation (day 14). In fact, the state of development is very variable in each litter (see fig.1 in Mattson et al., 1990). The possible origins of this diversity were discussed by Geisert and Schmitt (2015).

The rapid initial expansion is indicated by the number of cells, around 100 in early blastocysts and reaching 1000 shortly after shedding the zona pellucida on day 8, (Papaioannou \& Ebert, 1988). According to Geisert and al. (1982), the mitotic index and total DNA do not increase notably in ovoid blastocysts, suggesting just a shape modification of the forming conceptus (as already proposed by Perry, 1981). Note that the elongation zone observed by the first authors probably corresponds to the proliferating mesoderm described by Reima et al.,1993) and that the measures cited above may derive from T, E, and mesoderm cells. Blomberg et al.,2008) asserted that hyperplasia is constant during elongation. Cell proliferation was also observed in the ovoid bovine blastocyst (Degrelle et al., 2005). In any case, the cell redistribution betwteen the ovoid and tubular blastocyst might be compared to that occurring during embryonic convergent extension (described by Wallingford et al., 2002 and discussed by Tada \& Heisenberg, 2012). As discussed below, cell junction plasticity is important for relative cell movements: "convergence and extension correlate mostly with new junction growth" (Collinet et al., 2015).

All along its free life, the blastocyst is completely wrapped in the $\mathrm{T}$, except over the embryonic disc after the progressive loss of the overlying polar T cells or Rauber layer (not involved in implantation), occurring around day 10 (Barends et al., 1989, and cited references). The authors, using transmission electron microscopy, described the continuity of the cell layers of embryonic ectoderm and T, secured by common desmosomes; we observed also common cell junctions (not shown). The $\mathrm{T}$ is the first differentiated epithelium during the embryonic development. Polarized and bound by adherens junctions since compaction (Reima et al., 1993), the T cells, first either flat or rounded, become progressively cuboidal and columnar, constituting the mural $\mathrm{T}$. The $\mathrm{T}$ cells have a constant polygonal transverse section, a result of cell interactions, as a rule in epithelia (Gibson et al., 2011). In the ovine conceptus, T cells also maintain a polygonal shape during elongation (Wang et al., 2009).

Endoplasmic reticulum and Golgi vesicles are more abundant in the apical cytoplasm. The planar polarity of the T cells is also evidenced by the apical microvilli (brush border), distributed on the whole apical surface and particularly on the periphery of columnar cells. Other characteristics are the basolateral plasma membrane (PM) interdigitations, lateral cell junctions and the closely associated BL appearing at day 8 p.c. (Geisert et al., 1982). Outside the desmosomes and the adherens junctions (zonula adherens) distributed all along the lateral PM, the most apical tight junctions show the typical branched ridges in freeze-fracturing (not shown). These junctions form a belt (zonula occludens) common to epithelia (Shink et al., 2006), separating the PM in the apical domain specialized in exchanges with the outer milieu and the baso-lateral domain essentially devoted to cell-cell and cell-substratum anchorage.

\section{Trophectoderm roles}

The T plays the role of foeto-maternal barrier to the intercellular passage of large molecules, as shown by adding tannic acid to the fixative for electron microscopy. Increased contrast results on the apical PM, but it is stopped at the tight junctions (not shown). As an intrinsic expression of polarity, the semi-permeable $T$ is pumping fluid to inflate the blastocoele of the round blastocyst (via charge-sensitive pores of the tight junctions, see below), as initially described in the mouse blastocyst in a series of studies (see Biggers et al., 1978) and reviewed by Marikawa and Alarcon (2012). Similarly, a pig $\mathrm{T}$ cell line transports $\mathrm{Na}+$ to the basal side in vitro, producing 'domes' in the monolayer (Notarianni and Hurst, 1999). The concentration of aminoacids and sugars was found to differ in the blastocoele of bovine blastocysts from that of the outer milieu (Gopichandran and Leese, 2003).

Phagocytosis by the $\mathrm{T}$ before implantation was briefly reviewed (Bevilacqua et al., 2010). The authors recall the meaning of the term trophoblast, first given by Hubrecht (1889) for the nutritive tissue of the early embryo. The pig $\mathrm{T}$ takes from the intrauterine lumen all the elements necessary for the development of the conceptus, among which the so called histotrophe secreted by the endometrium (review by Bazer and Johnson, 2014). Correlatively, the T cells show surface caveolae and cytoplasmic inclusions (Geisert et al., 1982), that correspond to pinocytotic and phagocytotic activities (Barends et al., 1989; Baumbach et al., 1990), already observed in the ovine elongated conceptus (Wintenberger-Torres and Fléchon, 1974). T cells are moreover very rich in lipidic inclusions, specially in round blastocysts, obviously as a legacy of the oocyte, almost of the lecithic type.

The $\mathrm{T}$ signals the presence of the embryo to the mother by its secretions, e.g. oestrogens (peak at day 11-12) that may also play autocrine roles (Blomberg et al., 2008), and proteins such as interferons, whose possible functions on the uterus were not definitively deciphered by three groups examining the subject (Cenčic et al., 2003; Bazer et al., 2009 and Geisert et al., 2015), all working either on Large White or Meishan gilts. However the synthesis of interferon receptors was discovered in the conceptus and endometrium (D'Andréa and La Bonnardière, 1994; Jang et 
al., 2017). It was suggested by Joyce et al., (2008) that interferons may induce immune responses that are propicious for implantation. Other factors are also produced by the T such as retinoids (Parrow et al., 1998); their role is not elucidated, although it is known that retinoic acid binding proteins are synthesized by expanding blastocysts (Harney et al., 1990; Trout et al., 1991).

A new chapter of conceptus-endometrium interactions in pig was open with the discovery of information exchanges through extracellular microvesicles (Krawczynski et al., 2015). Since their description, (Keys and King, 1990), the role of these structures was unknown. Another type of factor present in the uterine lumen, the lysophosphatidic acid, may be able to promote the outgrowth of $\mathrm{T}$ cells (Jeong et al., 2016).

Instructions are also exchanged between the different cell types of the blastocyst. In the mouse blastocyst, e.g., some T factors were claimed to influence the differentiation (Hogan \& Tilly, 1981) and the proliferation (Behrendtsen et al., 1995) of the E. Transcriptomic and proteomic techniques enabled the discovery of a lot of transcription and growth factors, either autocrine or interacting between the tissues of ungulate conceptuses (review by Sandra et al., 2017).

In the pig, the T initiates attachment to uterine epithelium on day 14 , first step of an implantation without invasion (epitheliochorial type). In the meantime the conceptuses (amounting to around 10) are redistributed homogeneously within the two horns, probably by uterine peristaltic contractions like in the mouse (Hama et al., 2007), and under the control of phosphatidic acid,a multi-target substance (Ye and Chun, 2010). The initial blastocyst immobilization would process by 'gluing' according to Perry (1981). Later the filiform conceptuses become folded, each occupying $30-40 \mathrm{~cm}$ in the two contorted horns, providing optimal contact and exchanges necessary for gestation (Roberts et al., 1993). It is not known if a distant inhibition is at work between the elongating conceptuses so as to avoid overlapping. Their definitive location may be due to osteopontin, an extracellular matrix protein active at implantation (Johnson et al., 2014).

\section{Endoderm development}

The primitive $E$ cells, originating from delamination of the inner cell mass at day 6-7, are rapidly expanding as an epithelial monolayer under the T up to the abembryonic pole, reached around day 9 . The $\mathrm{E}$ cells underlying the embryonic disc are isolating it, together with the Rauber layer (until its loss); they form the visceral $\mathrm{E}$ and its lateral extension constitutes the parietal $\mathrm{E}$. The visceral $\mathrm{E}$ layer detaches from the BL under the embryonic ectoderm before mesoderm cells are intercalated, as observed by transmission electron microscopy (Barends et al., 1989). The authors further described, in all E cells, lateral cell junctions along with a relatively loose attachment to the BL by filopods, inflated rough endoplasmic reticulum, pinocytotic vesicles and apical microvilli facing the blastocoele cavity (reverse polarity versus T cells).

Geisert et al., (1982) observed E cells by scanning electron microscopy, after opening the blastocoele cavity. Away from the embryonic disc, the parietal cells, from cuboidal, become broader than $\mathrm{T}$ cells and look flattened; they take successively in time various forms such as starry, building a lacunar like layer during round to tubular blastocyst development, and finally fusiform in the filamentous conceptus. Although looking like mesenchyme cells, the starry E cells are polarized, e.g., with surface microvilli over the central nuclear area and on the outer borders. Like true epithelial cells, they are not labelled with antibodies to vimentin (Fléchon et al., 2004a).

In round (delayed?) blastocysts, some parietal E cells appear « in groups outlined by a thin line of short microvilli » (Geisert et al., 1982). In fact, this is the first evidence of the formation of polynuclear cells in the E, perhaps a strategy to keep up with the rapid proliferation phase by escaping cytokinesis? In the filamentous conceptus, nuclei resulting from a recent division remain coupled, all pairs oriented in the direction of elongation, as observed by scanning electron microscopy (not shown). A syncytial structure of the parietal fusiform $E$ cells is probably the rule in filiform conceptuses; this has also been described in ovine (Fléchon et al., 2007) and bovine conceptuses (Hue et al., 2015). It is difficult to imagin how these cells could migrate; they may just elongate.

\section{Endoderm roles}

Outside of extracellular matrix constituents (see below), E cells secrete other proteins, in vivo and in vitro, e.g. serum proteins like alpha-fetoprotein (Talbot at al., 2007). Some proteins of the blastocoelic fluid, as those detected in bovine (Jensen et al., 2014) and human blastocysts (Poli et al., 2015), are probably of E origin, as it builds an intermediary cell layer between the $T$ and the blasocoele cavity. Ultimately the E will differentiate into the yolk sac, and it is now thought that it will contribute to the definitive endoderm, as discovered in the mouse (Kwon et al., 2008). This interesting perspective is discussed by Frazer and Baron (2009). An evolutionary perspective on E was reviewed by Stern and Downs (2012).

Last but not least, as in other species, the $\mathrm{E}$ cells located at the anterior rim of the early embryonic disc play a role in defining the longitudinal axis of the pig embryo (Hassoun et al., 2009). The characteristics of these anterior ventral $\mathrm{E}$ cells were analysed in the bovine conceptus by Van Leeuwen et al., (2015).

After our publication on the syncytial fate of parietal $E$ cells in the ovine conceptus (Fléchon et al., 2007), colleagues pursued morphometric studies, that time on ovine T cells during elongation (Wang et al., 2009). However, no systematic analysis of the cell morphology and structure was done on the expanding porcine blastocyst. Let us now explore the 'cell mechanics' (Fletcher and Mullins, 2010) of the pig trophoblast.

\section{Cytoskeletal fibers and associated proteins}

\section{Elements of cytokeratins, associated junction proteins and lamins}

Cytokeratin proteins form tetrameric double-coiled coils of heterodimers building the IFs of around $10 \mathrm{~nm}$ in diameter which, notably, disappear during mitosis to form aggregates. Essentially cytokeratins 8, 18 and 19 are characteristic of unilaminar epithelial cells. The IFs, that may not just play a direct mechanical role, give cohesion to the cell monolayer via the lateral desmosomes (macula adherens), and eventual basal hemidesmosomes, to which they are bound (review by Bragulla and Homberger, 2009). Desmosomes are relatively stable structures in spite of integral membrane protein turnover and possible switching to high and low adhesiveness (Windorffer et al., 2002). Desmoplakins I \& II (isoforms) are the non-membranous proteins constituting the cytoplasmic plaque of the desmosomes. Desmocollin 1 is a Ca-dependant cadherin, an adhesive protein of desmosomes in epithelial cells (Garrod and Chidgey, 2008). 


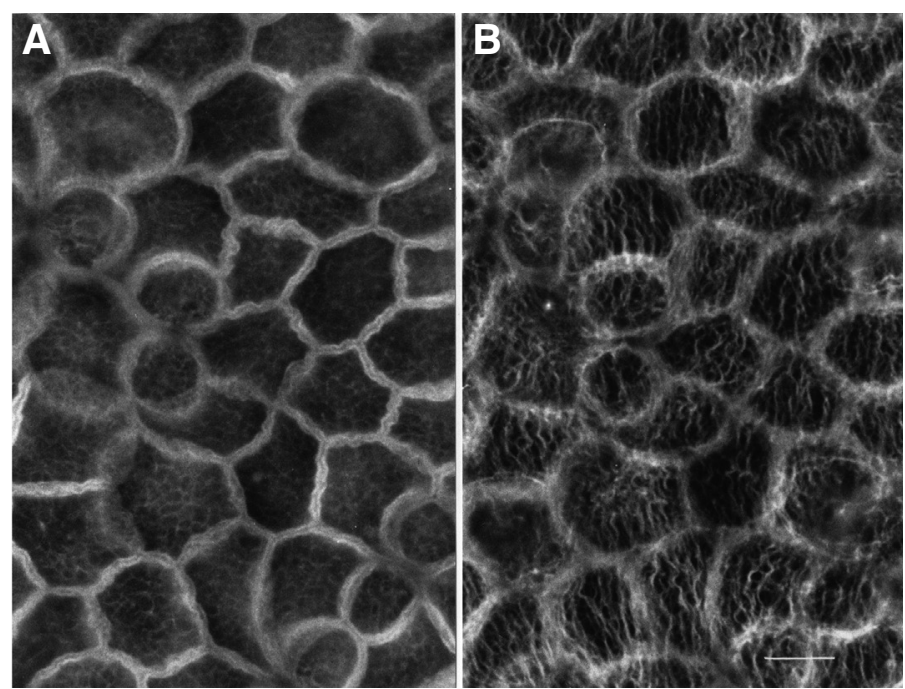

Fig. 1. Cytokeratins 8-18 at day 12, as observed at high magification. (A) Dense network of fluorescent intermediate filaments in the apical cytoplasm and intermediate filament bundles along the dark lateral plasma membranes. Pairs of post-cleavage cells have already the intermediate filament complement of interphase cells. (B) Outside basolateral bundles, the basal cytoplasm, contains parallel intermediate filaments in all cells (same field).

Lamins are IF proteins forming small intranuclear patches and a meshwork lining the inner nuclear membrane, called the nuclear lamina; it provides a framework for the nuclear envelope and anchoring sites for the peripheral heterochromatin (Lemaitre, 2015). Lamins of the two types, $A / C$ and $B$, are expressed in a developmentally regulated fashion, lamin $A / C$ being present only in differentiated cells (review by Dechat et al., 2010). Nuclear structural proteins including lamins maintain cell polarity (Chandramouly et al., 2007) and reciprocally the $\mathrm{BL}$ and the cytoskeleton influence the nuclear
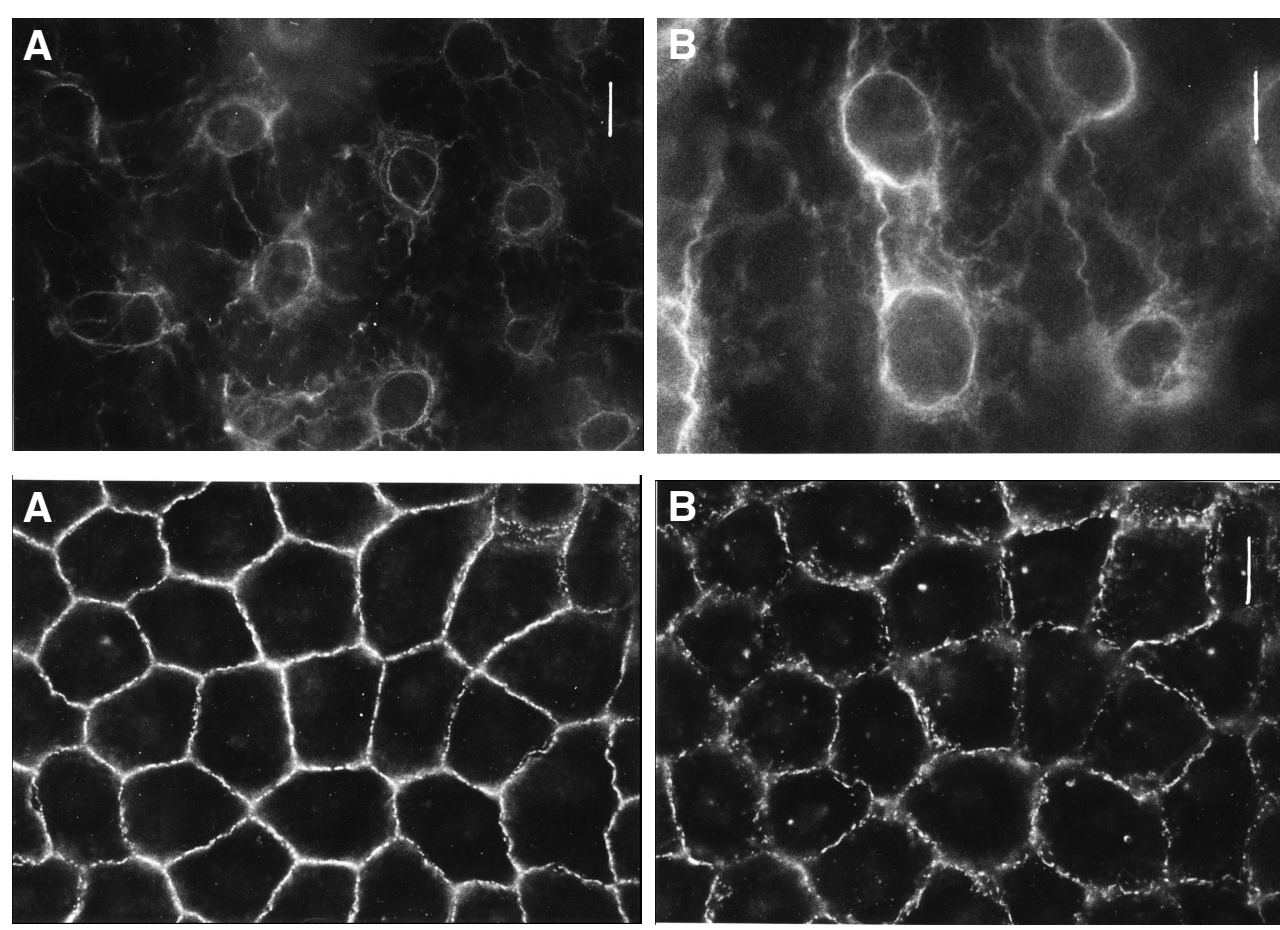

structure (Lelièvre et al., 1998). Ultimately the nuclear proteins are controlling the specific genes that are expressed in the different cell types, including epithelial cells (Gruenbaum and Foisner, 2015).

\section{Cytkeratins, associated junction proteins and lamins in the trophoblast}

In pig spherical blastocysts, IFs have been well identified and characterized by ultrastructural immunochemistry using monoclonal antibodies against cytokeratin 8, 18 and 19 (Fléchon, 1991). Identical results are obtained with a cytokeratin 8 antibody (see below). It is possible that some of the cytokeratins of $T$ cells are redundant, as knock out of the keratin 18 gene in the bovine blastocyst has no apparent effect on the T epithelium (Goossens et al., 2010).

In the elongating conceptus, a thick immunofluorescent layer of IFs is located along the lateral PMs of T cells (bound to desmosomes), and, in the cell apex, IFs form a dense meshwork (Fig. $1 \mathrm{~A})$; in the basal cytoplasm, the IFs become oriented parallel to the elongated aspect of the conceptus (Fig. 1B). This observation has been consistently made and confirms the mechanical role played by tonofilaments in the T cells during conceptus elongation. This is the first time a polarization of IFs was observed in cells of a mammalian embryo; however MFs parallel to the embryonic axis were already described in amphibians (Skoglund et al., 2008). The synthesis of cytokeratins reaches a maximum at the tubular blastocyst stage (Degrelle et al., 2009). In the filamentous conceptus, IFs are most abundant in the lateral and apical cytoplasm of $T$ cells (Suppl. Fig. S1).

The IFs form a network around the nuclei of cuboidal visceral E cells (Suppl. Fig. S2); They also enclose the nuclei and extend in the cytoplasm of parietal $E$ cells close to the embryonic disc in filamentous conceptuses (Fig. 2A). The cytoplasm of fusiform E cells contains IFs surrounding the common nuclei and elongating in the direction of the cell axis (Fig. 2B).

In T cells, a constellation of immunopositive desmoplakin (and desmocollin, not shown) signals dot the lateral PMs (Fig. 3A).The waved distribution of desmosomes in their basal region (Fig. $3 \mathrm{~B}$ ) is a reflection of the local PM interdigitations. In these columnar cells, the desmosomes are labelled at different levels of the lateral PMs (Suppl. Fig. S3A), whereas they are alined in a single row in flat E cells (Suppl. Fig. S3B). Almost no hemidesmosome-like structures were observed in $\mathrm{T}$ cells by transmission

Fig. 2 (Above). Cytokeratin 8 in parietal E cells of day-13 conceptus. (A) Inter mediate filaments wrap the nuclei and are radiating in the cytoplasm of polygonal and flattened cells. (B) Intermediate filaments are located around and between the nuclei of fusiform cells.

Fig. 3 (Below). Desmoplakin inT cells of a day-12 blastocyst. (A) Punctate labelling in the apex of the lateral plasma membranes corresponding to desmosomes. (B) Less recilinear labelling in the basal region (same field). 


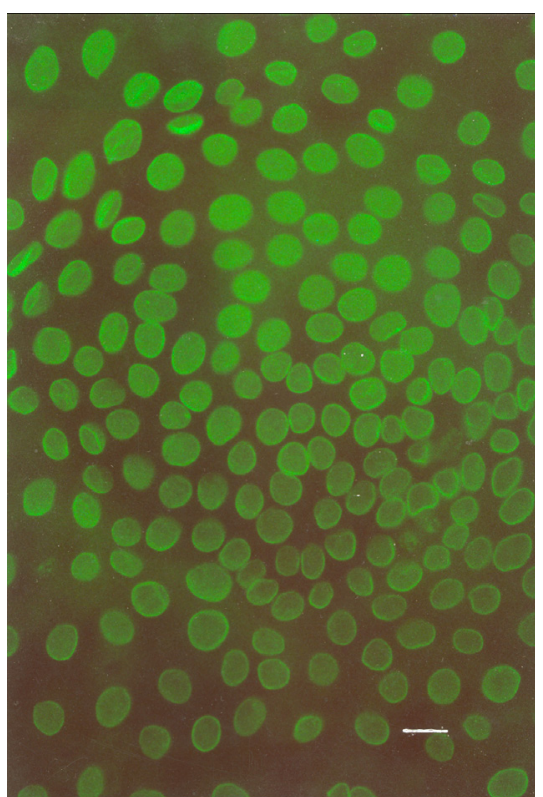

Fig. 4. Lamins $\mathbf{A} / \mathbf{C}$ in a day-10 blastocyst. Immunolocalization in the nuclear periphery of visceral E cells under the embryonic disc.

\section{electron microscopy.}

Lamins A/C were not constantly reported to be expressed in the nuclei of pig T cells (Foster et al., 2007; Lee et al., 2007). The results may differ according with embryonic stages and with the methodologies used. The nuclei of $\mathrm{T}$ cells appear differentially smaller than those of E cells after staining e.g. with DAPI and this dissimilarity can be used to ascertain the focus level in the trophoblast. In our hands, antibodies to lamins A/C obviously stain the nuclear periphery in E cells (Fig. 4), and only faintly in T cells of early blastocysts (not shown). This may mean that Tcells are initially not stably differentiated, as already mentioned. Notably, nuclei of T cells differentiated in vitro are labelled (Fléchon et al., 1995).

\section{Tubulins}

Tubulin isotypes comprise two main classes, alpha and beta. Their heterodimers form self-assembled MTs (20-25 nm in diameter) from the cytoplasmic pool of monomeres. MT assembly is nucleated on mitotic organizing centres, e.g. a centrosome periphery, and MTs show dynamic instability (oscillation between assembly and disassembly at the free end). They play several roles: chromosome segregation in mitosis, intracellular transport, and support of cell shape due to their stiffness (Hawkins et al., 2010). In monostratified epithelia, the spindle axis is oriented parallel to the cell layer (Reinsch and Karsenti, 1994), under the influence of the BL (Théry et al., 2005).

\section{Tubulins in the trophoblast}

The MTs of T and E cells, of classical ultrastructural aspect (not shown), were characterized in day-8 blastocysts with monoclonal antibodies to alpha-tubulin. As expected, the distribution of MTs depended on wether the cells were in interphase or mitosis. In interphase T cells, MTs were abundant in the apical cytoplasm and formed a kind of barrel around the nucleus, as in other epithelial cells (Tang and Marshall, 2012), probably contributing to maintenance of the cuboidal shape of the T cells (Fléchon, 1991).
These cells are dividing in the epithelial plane and, as observed by transmission electron microscopy, the midbodies can persist for some time after cytokinesis, as an intercellular bridge located at the cell apex (not shown). In expanded blastocysts, midbodies are abundant in T cells, the majority of which are oriented in the same direction (Fig. 5A). Although lacking of statistical analysis, this observation may at least suggest that already before elongation, the mitoses are starting to be polarized. Note that during mammalian primitive streak formation, a reorientation of mitoses and a parallel alinement of cell divisions were observed (Halacheva et al., 2011). At the same stage, MTs are all distributed at the periphery of interphase nuclei (Fig. 5B). In the tubular conceptus, midbodies are still numerous in T cells (Fig. $5 \mathrm{C}$ ). These stuctures were also observed in the embryonic ectoderm where cell intercalations were visible (Fig. 2B in Fléchon et al., 2004a). Thus T cells are typical of other vertebrate epithelia that are maintaining cell to cell cohesion while proliferating (Guillot and Lecuit, 2013; Herszterg et al., 2014).

Polygonal E cells (and E cell lines, Talbot et al., 2007) contain perinuclear and radiating MTs and show midbodies (Fig. 5D). No documentation on tubulin distribution is available for the filiform conceptus.
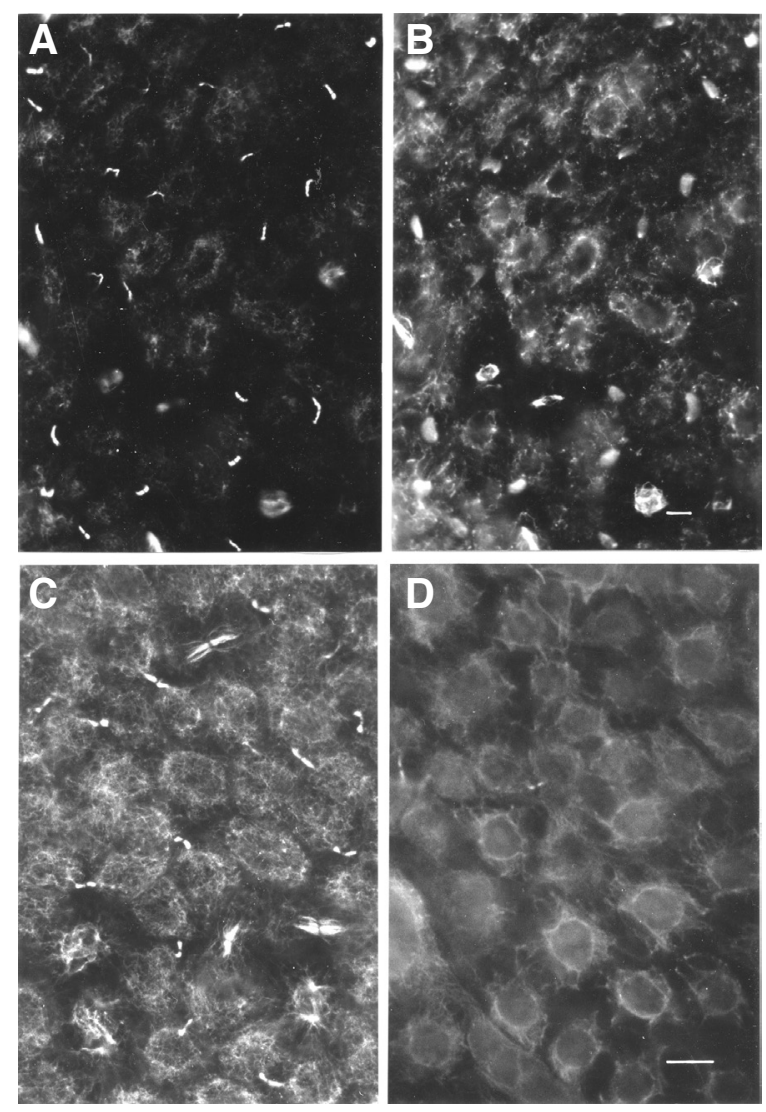

Fig. 5. Tubulin-alpha in T cells of ovoid blastocysts. (A) At day 11, midbodies in the apical focus plane are mostly oriented in the same direction. (B) Focus plane through the dark nuclei surrounded by fluorescent points corresponding to MTs in transverse section. (C) At day 12, in the T cell apex, the midbodies are also in majority similarly oriented; the microtubules are surrounding the top of the nuclei. (D) At the same stage, microtubules wrap the nuclei and extend radially in the cytoplasm of underlying parietal E cells where midbodies are visible. 


\section{Actin and associated proteins}

The actin cytoskeleton is very dynamic. Actin monomers polymerise into F-actin elongating at both extremities, one slow and one fast growing end, forming MFs (5 nanometers in diameter). F-actin binds proteins of the adherens junctions and interact with, among other proteins, non-muscle myosin II. The latter hydrolyses ATP to produce energy allowing its movement along F-actin; in this way active contractile forces are generated in the furrow (contracting ring) during cytokinesis, in intracellular transport, in changes of cell shape, in migration during development and in mechanotransduction (Ishratsch et al., 2014). Moreover, MFs surrounding the nucleus control its shape (Khatau et al., 2009). Bipolar double macromolecules of myosin crosslink actin (Landswerk and Epstein, 2005) and actomyosin networks undergo pulses of assembly and disassembly (Munjal et al., 2015). The integrating role of the actin cytoskeleton was reviewed by Lecuit et al.,2011).

Ezrin or cytovillin is a PM-associated protein linking F-actin fibers in microvilli (Turunen et al., 1989). Interactions of actin and actin-binding proteins were reviewed by Hansen \& Kwiatkowsky, (2013) and Ivanov \& Naydenov, (2013).

\section{Actin in the trophoblast}

We successfully used heavy meromyosin to characterize Factin, in both cell types, at the ultrastructural level (not shown). Rhodamine-phalloidin and anti-actin antibodies were applied undifferently to detect F-actin in round blastocysts (Albertini et al., 1987). The authors found a continuous fluorescent labelling along the lateral PMs of T cells and of visceral E cells. The apex was also stained in T cells. A similar distribution of F-actin in T cells of the later preimplantation stages was published by Mattson et al., (1990). The authors described spindle-shaped T cells in 'constricted' regions of elongating blastocysts. In fact, it is the result from a mechanical artefact occuring in places where the fragile conceptus is twisted during recovery. As stated above, T cells stay polygonal. On the contrary, when the cell preservation is optimal, F-actin, in addition to its binding to lateral PMs, is found at the apical surface of T cells, exhibiting the aspect of a brush border (Fig.
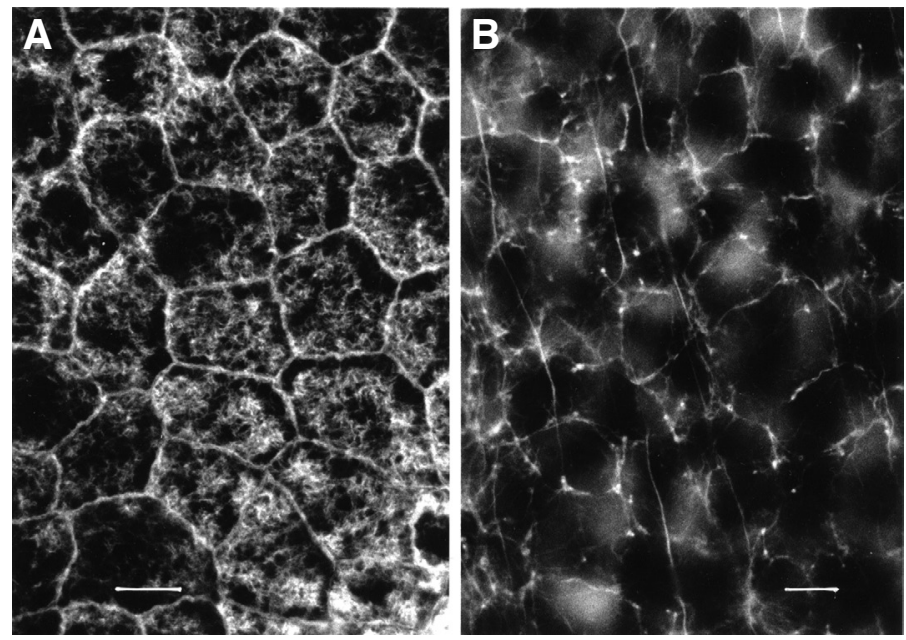

Fig. 6. Rhodamine-phalloidin stained F-actin in day -12 blastocyst. (A) Microfilaments in the apical plasma membranes (brushborder) and along the lateral plasma membranes of $T$ cells. (B) F-actin bound to the basolateral plasma membrane of $T$ cells and organized in long parallel microfilaments in the E cell layer.
6A). F-actin spots follow the basolateral border of $T$ cells and the long fluorescent filaments are belonging to fusiform $E$ cells of the ovoid conceptus(Fig. 6B). F-actin also forms a meshwork around T cell nuclei, above the labelled basolateral PMs (Suppl. Fig. S4A). The microvilli of $T$ and $E$ cells are also labelled with anti-cytovillin antibodies (not shown).

F-actin is mainly distributed in the apex of cuboidal E cells, in the microvilli over the bumped nuclear area of flat cells in the elongating conceptus and along the borders of these cells, that are lined with microvilli (as well as in E cell lines, Talbot et al., 2007); this is most clearly observed around lacunae (Suppl. Fig. S4B). $\mathrm{F}$-actin is as sparce in the basal cytoplasm as the filopods are. Bottom located F-actin should be of prime importance for $E$ cells if they are able to migrate. Absence of F-actin-myosin II interaction induce defect in cell adhesion and in visceral $E$ formation in the mouse embryo (Conti et al., 2004)..

Actin has been implicated in the contraction of round blastocysts of different species observed in vitro, either before or after hatching. Different interpretations, artefact of manipulation, help for hatching or renewal of blastocoelic medium were given (Nimura et al., 2009; Marcos et al., 2015).

\section{Characteristics of cell adhesion molecules of adherens junctions and of integrins}

\section{Cadherins and catenins}

E-cadherin (or uvomorulin) is a cell-adhesion molecule with a large external domain, that self binds between adjacent cells; its short intracellular tail is engaged in calcium-dependant interactions in adherens junctions with the cytoplasmic glycoproteins alpha- and beta-catenins and thereby with F-actin (Yonemura, 2011). E-cadherin is also associated with F-actin and localized at the tight-junctions where transmembrane proteins constitute a barrier against intercellular solutes; e.g. the claudin proteins form small charge-sensitive pores and the tight junctions also provide pores for larger solutes (Günzel and Yu, 2013). These junctions also build a border between the apical and basolateral PM domains which differ in their composition. Binding both F-actin and barrier proteins, ZO-1 is a representative of a family of membrane associated scaffolding proteins characteristic of tight junctions (Van Itallie et al.,2009). Tight junction proteins ultimately regulate cellular gene expression (Matter and Balda, 2007).

Claudins are internalized when epithelial cells move within their sheet without loosing contact (Matsuda et al., 2004). Similarly, E-cadherin is recycled by endocytosis (Yap et al., 2007; Tian et al., 2011). Adherens junctions are considered flexible structures, i. e. « adaptable interfaces during convergent extension » (Garrod and Chilly, 2008) and in morphogenetic events where cell shapes change (Brigaud et al., 2015), like E cells. Whereas adherens junctions acquire stability by binding to F-actin via E-cadherin, the latter regulating its polymerization, $\mathrm{F}$-actin controls cadherin endocytosis (Collinet and Lecuit, 2013). Cadherin-operated adhesion induce a wide range of regulatory processes, e.g. cell polarization (Dupin et al., 2009) and the organization of fibronectin in the BL (Dzamba etal., 2009). Junction proteins were reviewed by Harstok and Nelson (2008).

Vinculin is a cytoplasmic protein (in the same family as alphacatenin) binding focal adhesion sites of the PM to F-actin, and it is also present in adherens junctions (Ziegler et al., 2006). 


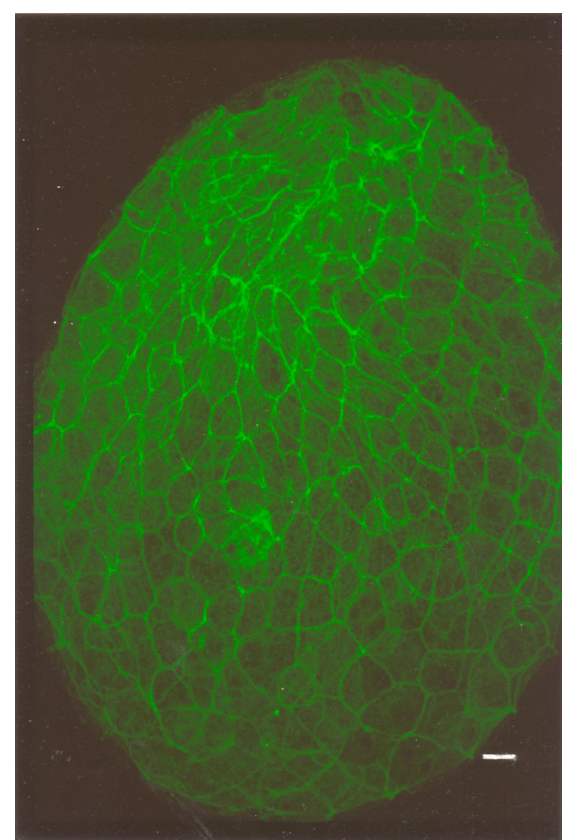

Fig. 7. Immunolocalization of E-cadherin in $\mathrm{T}$ cells of a day-8 ovoid blastocyst. All lateral plasma membranes in focus are clearly stained.

\section{Integrins}

Integrins are heterodimeric Ca-independant transmembrane glycoproteins composed each of an extracellular 'head' and two short cytoplasmic 'tails' that are subject to turnover (Bridgewater et al., 2012). Combinations of beta-integrin moieties with different alpha moieties are specific for either fibronectin, laminin, or collagen that are bound to the external associated ends. The internal roots build large inside-outside signalling complexes at focal contacts. Bidirectional information is force transduced, by bound actin, via couples of alpha-beta integrins (review by Li et al., 2016).

\section{Cell adhesion molecules in the trophoblast}

\section{Cadherins and catenins}

The lateral PMs of the T cells show an apparent continuous labelling with antibodies to cell adhesion molecules of the E-cadherin type (Fig. 7). At high magnification, fine fluorescent dots are considered as adherens junctions (not shown). Several works show that mutations in cadherin and catenin inhibit the development of the T in the mouse blastocyst (see e.g. Stephenson et al., 2010).

Vinculin is detected at adherens junctions as a thin line on the lateral PMs and as dots at the limit of lateral and basal PMs (Suppl. Fig. S5). The expression and belt-like localisation of tight junction proteins ZO-1 and occludin were described in preimplantation parthenogenetic pig blastocysts (Xu et al., 2012).

\section{Integrins}

Integrins expressed in the pig T are alpha 1, 4, 5, V, and beta 1 and 3 (Bowen et al., 1996). Whereas F-actin is located in the apical cytoplasm and along the lateral PMs (Suppl. Fig. S6A), the integrin complex alpha-5-beta-1 is immunolocalized to the basolateral PMs of a late ovoid blastocyst (Suppl. Fig. S6B). Although T cells are bound to the BL, almost no focal adhesion sites were observed on the basal PM itself, the opposite of cells moving in vitro on a substratum (Wolfenson et al., 2011). However, the dots of F-actin along the basolateral PMs (Suppl. Fig. S7A), where vinculin is found (see above), are evident binding sites; fibronectin is also observed to accumulate around the basis of $\mathrm{T}$ cells, again in an ovoid blastocyst (Suppl. Fig. S7B).

\section{Characteristics of the fibrous proteins of the basal lamina}

\section{Fibronectin}

Fibronectin is a glycoprotein present in many isoforms as a result of alternative splicing. Cellular fibronectin dimers assembly into fibrils in the $B L$ is facilitated by tension with bound integrins (such as alpha-5-beta-1) and collagen (Leiss et al., 2008). The elasticity of the resulting meshwork was observed in vitro (Ohashi et al., 1999). Fibronectin has multiple roles in cell adhesion, growth, differentiation and migration (Pankov and Yamada, 2002), notably in embryos (Darribère and Schwartzbauer, 2000).

\section{Collagen IV and laminins}

Collagen IV is a characteristic glycoprotein of the BL where it binds to fibronectin and to itself by its globular ends; it forms fibrils and a flat network, a resistant support for the overlaying epithelial cells (Pöschel et al., 2014). Extracellular matrix is built to resist to applied forces (Solan et al., 2009).

Laminins are high-molecular-weight glycoprotein components of the BL. Their terminology is based on their heterotrimeric polypeptide chain composition. On the central domain, the long arm binds to integrins and the short arm is responsible for homoaffinity, building sheets associated to collagen IV and cellular fibronectin (Yamada and Sekiguchi, 2015).

\section{Cooperative roles of ECM proteins in epithelia}

Laminins and collagen IV are obligatory components for maintaining planar epithelium differentiation and function (Plachot et al., 2009). Cell-matrix and cell-cell adhesion interact via the actin network and integrins (Burute and Théry, 2012). In addition to control of epithelial specificity and of genome regulation through cell signalling via cryptic sites exposed by mechanical tension (Kim et al., 2011), the BL plays the roles of molecular filter, and of water and growth factor storage (Asem et al., 2000)).

The interaction of all these cellular and extracellular elements in morphogenesis was reviewed by Lecuit etal., 2011). The importance of an extracellular matrix substratum to obtaining polarisation of epithelial cells in vitro was discussed by Inman and Bissel (2010).

\section{Fibrous proteins of the basal lamina in the trophoblast}

\section{Protein synthesis}

Using a monoclonal antibody to cellular fibronectin reveals, on the basal face of $T$ cells, a fibrous meswork progressively woven since the round blastocyst stage onward (Suppl. Fig. S7B). The perinuclear sites of fibronectin synthesis in E cells (Fig. 8A) were first described in day-11 blastocysts by Richoux et al., (1989), using antibodies to plasma fibronectin; however the possibility that fibronectin would be synthesized also by $T$ cells was not confirmed. This is conforted by the fact that the BL apposed to the inner cell mass is disposed only along the E. Endoplasmin, a marker of the endoplasmic reticulum (Randow and Seed, 2001) is similarly located in E cells (not shown). Effectively, fibronectin is elaborated 
in the enlarged perinuclear endoplasmic reticulum of $E$ cells as observed by immunoelectron microscopy (not shown).

Laminin (Fig. 8B) and collagen (not shown) are also synthesized in $E$ cells. Laminin was detected after the completion of the $E$ cell layer whereas fibronectin appeared with the primitive $E$ (Richoux et al., 1989); it is not known when the secretion of collagen IV begins, however the BL can start to assemble in the absence of collagen IV (Poeschl et al., 2004).

\section{Protein distribution}

Collagen IV forms a network (not shown). Fibronectin also forms a network and long parallel fibers (Fig. 8A), like laminin (Fig. 8B), an indication of a relationship between the directional polarity of the conceptus and of the BL constituents. In his review on mechanotransduction, Schwartz (2010) stated that «matrix assembly usually occurs in a directional manner according to the applied force ". In the pig conceptus, the continuous synthesis of the BL glycoproteins may result in a progressive increase of its complexity as shown by the different stuctures (meshwork and fibrils) observed on the T and E side (Fig. 8A). In vitro, the molecular morphology and distribution of the substrate control epithelial cell behaviour (Deng et al., 2017) and e.g. their spreading may be progressively oriented in one direction (Haga et al., 2005). A particular aspect of the BL was observed in the conceptus extremity. Fibronectin was distributed in parallel arrays perpendicular to the axis of fusiform E cells, as if the BL meshwork was stretched in the direction of elongation (Fig. 9). Other components of the BL, such as proteoglycans (Lozzo and Schafer, 2015), were not analysed in the pig conceptus.

\section{Role of the basal lamina in the trophoblast}

The eventual role of the BL as a selective sieve was questioned; it does not inhibit diffusion of ferritin injected in the blastocoele
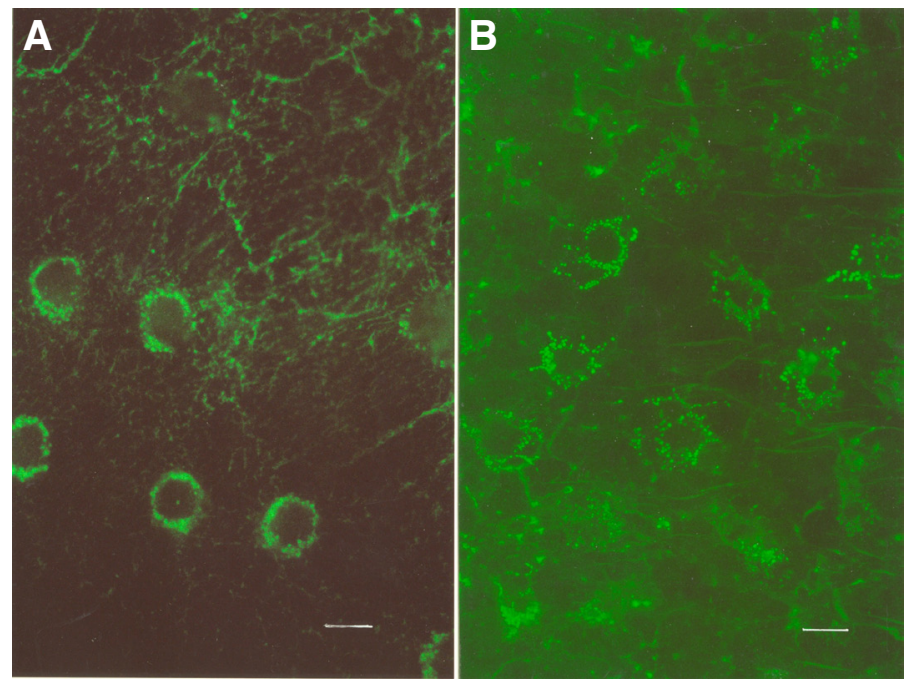

Fig. 8. Comparative immunolocalization of fibronectin and laminin of the basal lamina in day-12 blastocysts. (A) Cellular fibronectin distributed in perinuclear dots of parietal E cells and in the basal lamina as a network, more or less polygonal like T cells and as parallel filaments closer to $E$ cells. Note that the focus plane is opportunely oblique. (B) Laminin in small dots around the nuclei and in the cytoplasm of $E$ cells and as long parallel filaments in the basal lamina.

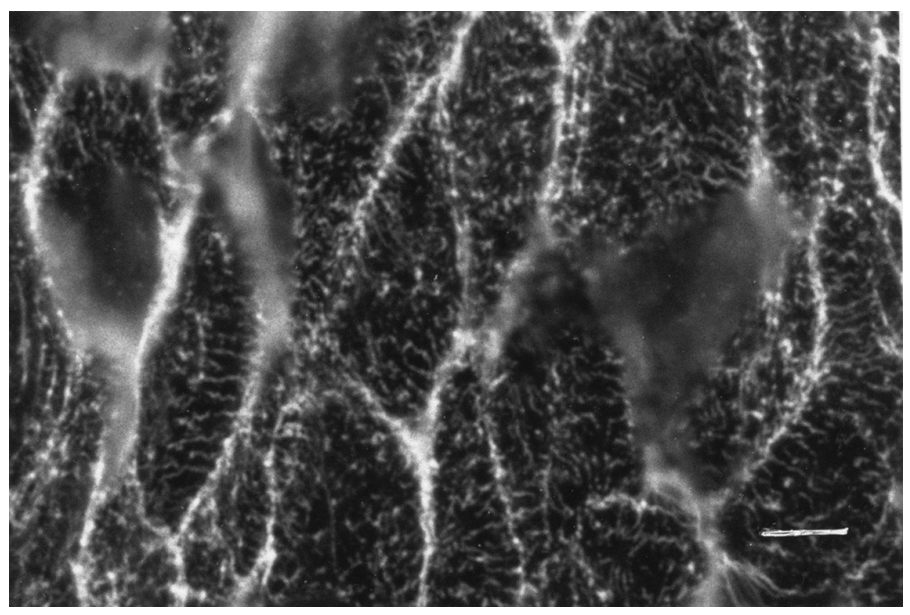

Fig. 9. Fibronectin localisation in the bulbous tip of day-13 filamentous conceptus. Fibronectin distributed along the basal borders of $E$ cells and forming kinds of fibers mostly aligned in a direction transverse to these fusiform cells.

(Barends et al., 1989). This might be caused by BL discontinuities. The BL is a support for T cells and either an oriented conveyor or a substrate for the eventual migration of $E$ cells. The relative affinity of porcine $\mathrm{E}$ cells for different components of the BL was tested in vitro in the following experiments. E cells derived from inner cell masses were tested positively for their ability to migrate on fibronectin and laminin, negatively for collagen IV. Integrin inhibition was not effective for adhesion on fibronectin (owing to an alternative mechanism?). The described migration was also not affected by inhibition of metalloproteinase, an enzyme also promoting cell proliferation, (Schilperoort and Menino (2002), so it was not facilitated by partial BL lysis. These results do not take in account the possible secretion of BL components by $E$ cells, and are not a proof that these cells migrate in vivo. The role of the $\mathrm{BL}$ in the maintenance of differentiated porcine T cells was demonstrated by the derivation of $\mathrm{T}$ cell lines only when cultured on feeder cells producing a complex extracellular matrix (Fléchon and Notarianni, 1995) or on a porous filter coated with collagens (La Bonnardière et al., 2002). In the latter case the cells produced interferons and in both cases, they formed a polarized epithelium expressing a cell surface marker specific for pig trophectoderm (Whyte et al., 1984). Again, interferon secretion was observed at the apex of T cells, as well as in the medium of cultured trophoblastic vesicles where the normal morphology of the trophoblast is preserved, including the presence of the BL, as they are simply obtained by sectioning of filamentous conceptuses (D'Andréa et al., 1994). Noteworthy is the fact that trophectoderm vesicles do not elongate in vitro, as observed in the sheep species, whereas trophoblastic vesicles transplanted in vivo can elongate and maintain the corpus luteum (Fléchon et al., 1986). This means that elongation is controlled by the uterus, contrary to the synthesis of interferons. However, the regulation of elongation may be just mechanical, as shown by culture of the cow blastocyst in a tube (Vejlsted et al., 2006). Another $\mathrm{T}$ cell line cultured on feeders produced retinoids, as $\mathrm{T}$ cells in vivo (Parrow et al., 1998). It is important to remember that trophoblast cell lines may differ depending on their origin from early or late blastocysts and that, as noted above for the BL, the culture substrates like Matrigel may contain growth factors (Talbot 
and Caperna, 2015).

Lines of $E$ cells have also been obtained on feeders (Talbot et al., 2007), and it would be interesting to check if they could differentiate in long term culture without added extracellular matrix. In short culture, this was obtained with bovine $E$ cells on a plastic, feeder-free support (Hue et al., 2015).

\section{Conclusion}

This review puts emphasis on the planar polarity of pig $T$ and $\mathrm{E}$ epithelial cells observed by scanning and transmission electron microscopy and by immunofluorescence, using many cytochemical markers of such monolayers. All the elements of the cytoskeleton, associated junctions, integrins and the adherent BL provide complex interactions and /or feedback to maintain the cytoplasmic and nuclear status of these cells. In addition to the interplay of MFs and IFs, MTs were shown to contribute, by their stiffness, to framing the shape of columnar T cells and stellar E cells. The mechanical constraints, internal and external, to the trophoblast are sufficient to explain how is maintained the polarity and continuity of both cell layers. Although the present work may look like only a documented confirmation of accepted knowledge, it presents some primetime observations and sheds new light on some questions asked in the introduction, such as:

- After each cell division and during the shape transition of the conceptus, specially from ovoid to tubular, there must be some flexibility in cell-cell adhesion and cell binding to the elastic BL (allowing cell intercalations); this may be explained by the constant renewal of cellular and extracellular proteins. Moreover, it was proposed that extracellular matrix also move during morphogenesis (Loganathan etal., 2016). The composition and structure of the BL may evolve with time, e.g. by sequential changes in the synthesis of its components and by induction of their polymerization into fibrils after binding to cells. This is probably the case in the pig conceptus, where extracellular matrix is continuously secreted during elongation and lot of fibers are formed (Fig. 8). The question is how elongation does occurr, by active or passive migration of both $\mathrm{E}$ and $\mathrm{T}$ cells. Therefore, we have suggested that the concept of convergent extension may also apply to extraembryonic tissues. This is probably the issue for $T$ and $E$ cells in vivo where there is no free space to invade, except for $E$ cells in the early round blastocyst. The situation is different in vitro where two cases may occur at least for T cells unable to produce their own BL. When these cells are cultured on an adhesive substrate and build an epithelium, the condition is similar to that in vivo, except that domes may be formed (lack of space). If a free area exists at the periphery of the culture, cell spreading is possible. When no epithelium is formed, cells may freely migrate and it is not possible to conclude that they were originally able to behave identically in vivo, like mesoderm cells do. Although «even in sheets with no free leading edge, epithelial cells can migrate collectively», as reported by Sato et al. (2015), collective cell migration does probably not apply to trophoblast cells, at least during tubular elongation, resulting from random nuclear divisions associated with the extension of the BL.

- The directional growth of the trophoblast is under pressure from the limited space available to the multiple conceptuses in the lumen of the uterine horns. Mitotic spindles in $T$ and $E$ cells are not only restricted to alignement within the plane of the cell layers by mechanical constraints, but are also frequently or even uniquely oriented parallel to the conceptus axis. The proliferation of the $\mathrm{E}$ cells inside of the continuous T monolayer may be compared to the growth of an epithelial tube (Lubarsky et al., 2003) in which the unidirectional orientation of cell divisions maintains a constant tube diameter (Fischer et al., 2005). Several nuclei ultimately become longitudinally aligned, resulting from a lack of cytokinesis inside myofibrillar looking E cells. Mechanical forces exerted during expansion and elongation may induce the observed orientation of IFs in parietal T cells and polynuclear $E$ cells, and of extracellular matrix filaments in the BL. All the above data comply with the high sensitivity of the cytoskeleton to spatial boundary conditions (Vignaud et al., 2012). As a clear outcome of this review, the development of the porcine trophoblast can be partly explained by the phenomena of mechanobiology. This field of cell biology, reviewed by Eyckmans et al. (2011), seems to find application in many types of cells and tissues including embryos (Krupinski et al., 2011, reviewed by Mammoto et al., 2012) and during implantation (Kim et al., 2010).

- In the E, there are no proliferation crypts like, e.g., in intestinal epithelium, although it would be interesting to test wether the first primitive $\mathrm{E}$ cells have stem cell characteristics or not. On the other hand, a line of porcine T cells obtained from mesenchyme cells induced with nuclear reprogramming factors has been described (Ezashi et al., 2011). T cell lines (as well as E cell lines), easy to obtain from early blastocysts, have characteristics of T stem cells, according to Hou et al. (2015). Finally T cell lines may be immortalized (Zhang et al., 2016). The T and E cell lines constitute models of extraembryonic epithelial cells useful for in vitro experiments.

\section{End note}

$\mathrm{T}$ and $\mathrm{E}$ cells constitute what we call the trophoblastic entity, a mutual beneficial association where $E$ cells secrete the BL components necessary for $\mathrm{T}$ cell polarisation, whereas $\mathrm{T}$ cells bind and consequently induce modifications to this BL. The T may also produce factors for the differentiation of $E$ cells. Lastly, it is worth keeping in mind that the prime role of the trophectoderm is to take up most of the nutriments and uterine factors for the whole conceptus (the surface of the embryonic disc is quantitatively negligible).

Many questions asked along this review remain open, among which: why and how is induced the loss of the Rauber layer? Is there any long term migration of T and E cells? How is cytokinesis inhibited in parietal E cells? What is the fate of the polynuclear $E$ cells after implantation? Which part of the extraembryonic E may contribute to the definitive $E$ ? Do porcine $T$ or $E$ stem cells exist and what would be their nature versus those of mouse cells?

We hope that this review on the intricate constitution of the pig trophoblast and some of our speculations concerning its evolutive structure and function will renew research interest in the biomechanics, physiology and molecular biology of mammalian conceptuses that undergo elongation prior to implantation.

\section{Acknowledgements}

Best thanks to Elena Notarianni, Guojung Sheng and Christian Viebahn for critical reading of the manuscript and to Neil Talbot for editing the text. 


\section{References}

In order to limit the number of references, and to propose the most fresh knowledge, mainly recent works and reviews on each subject are cited. We apologise for the omitted authors of original research articles.

ALBERTINI, D.F., OVERSTROM, E.W. and EBERT, K.M. (1987). Changes in the organization of the actin cytoskeleton during preimplantation development of the pig embryo. Biol. Repro. 37: 441-451.

ASEM, E.K., STINGLEY-SALAZAR, S.R., ROBINSON, J.P. and TUREK, T.J. (2000). Identification of some components of the basal lamina of avian ovarian follicles. Poultry Sci. 79: 589-601.

BARCROFT, L.C., HAY-SCHMIDT, A., CANEVEY, A., GILFOYLE, E., OVERSTROM, E.W., HYTTEL, P. and WATSON, A.J. (1998). Trophectoderm differentiationin in the bovine embryo: characterization of a polarized epithelium. J. Reprod. Fertil. 114: 327-339.

BARENDS, P.M.G., STROBAND, H.W.J., TAVERNE, N., TE KRONNIE, G., LEEN, M.P.J.M., and BLOMMERS, P.C.J. (1989). Integrity of the preimplantation pig blastocyst during expansion and loss of polar trophectoderm (Rauber cells) and the morphology of the embryoblast as an indicator for developmental stage. $J$. Reprod. Fertil. 87: 715-726.

BAUMBACH, G.A., BARTLEY, N.G., KATTESH, H.G. and GODKIN, J.D. (1990). Immuno-localization and endocytosis of the uterine secretory protein, uteroglobin, in the preimplantation pig trophectoderm on day 11 of pregnancy. Anat. Embryol. 182: $563-568$

BAZER, F.W. AND JOHSON, G.A. (2014). Pig blastocyst-uterine interactions. Differentiation 87: 52-65.

BAZER, F.W., SPENCER, T.E., JOHNSON, G.A. (2009). Interferons and uterine receptivity. Sem. Reprod. Med. 27: 90-102.

BEHRENDTSEN, O., ALEXANDER, C.M. and WERB, Z. (1995). Cooperative interactions between extracellular matrix, integrins and parathyroid hormone-relared peptide regulate parietal endoderm differentiation in mouse embryos. Development 121: 4137-4148.

BETTERIDGE, K.J. and FLECHON, J-E. (1988). The anatomy and physiology of preattachment bovine embryos. Theriogenology 29: 155-187.

BEVILACQUA, E., HOSHIDA, M-S., AMARANTE-PAFFARO, A., ALBIERI-BORGES, A. and GOMES, S.Z. (2010). Trophoblast phagocytic program: roles in different placental systems. Int. J. Dev. Biol. 54: 495-505.

BIGGERS, J.D., BORLAND, R.M. and LECHENE, P. (1978). Ouabain-sensitive fluid accumulation and ion transport by rabbit blastocysts. J. Physiol. 230: 319-330.

BLOMBERG, L.A., HASHIZUME, K. and VIEBAHN, C. (2008). Blastocyst elongation, trophoblastic differentiation, and embryonic pattern formation. Reproduction 135: 181-195.

BOWEN, J.A., BAZER, F.W. and BURGHARDT, R.C. (1996). Spatial and temporal analyses of integrin and Muc-1 expression in porcine uterine epithelium and trophectoderm in vitro. Biol. Reprod. 55: 1098-1106.

BRAGULLA, H.H. and HOMBERGER, D.G. (2009). Structure and functions of keratin proteins in simple, stratified, keratinized and cornified epithelia. J. Anat. 214: 516-559.

BRIDGEWATER, R.E., NORMAN, J.C. and CASWELL, P.T. (2012). Integrin traffiking at a glance. J. Cell Sci. 125: 3695-3701.

BRIGAUD, I., DUTEYRAT, J-L., CHIASTA, J., LE BAIL, S., COUDERC, J-L. and GRAMMONT, M. (2015). Transforming growth factor beta/actinin signalling induces epithelial cell flattening during Drosophila Oogenesis. Biol. Open 4: 345-354.

BURUTE, M. and THÉRY, M. (2012). Spatial segregation between cell-cell and cellmatrix adhesions. Curr. Opin. Cell Biol. 24: 1-9.

CENČIC, A., GUILLOMOT, M., KOREN, S. and LA BONNARDIERE, C. (2003). Trophoblastic interferons: do they modulate uterine cellular markers at the time of conceptus attachment in the pig? Placenta 24: 862-869.

CHANDRAMOULY, G., ABAD, P.C., KNOWLES, D.W. and LELIEVRE, S.A. (2007). The control of tissue architecture over nuclear organization is crutial for epithelial cell fate. J. Cell Sci. 120: 1596-1606.

COLLINET, C. and LECUIT, T. (2013). Stability and dynamics of cell-cell junctions. Progr. Mol. Biol. Transl. Sci. 116: 24-47.

COLLINET, C., RAUZI, M., LENNE, P.F. and LECUIT, T. (2015). Local and tissue- scale forces drive oriented junction growth during tissue extension. Nat. Cell Biol. 17: 1247-1258

CONTI, M.A., EVEN-RAM, S., LIU, C., YAMATA, K.M. and ADELSTEIN, R.S. (2004). Defect in cell adhesion and the visceral endoderm following ablation of non muscle myosin heavy chain HA in Mice. J. Biol. Chem. 270: 41263-41266.

D'ANDREA, S., CHOUSTERMAN, S., FLECHON, J-E. and LA BONNARDIERE, C. (1994). Paracrine activities of porcine trophoblastic interferons. J. Reprod. Fertil. 102: 185-194

DARRIBERE, T. and SCHWARTZBAUER, J.E. (2000). Fibronectin matrix composition and organization can regulate cell migration during amphibian development. Mech. Dev. 92: 239-250.

DECHAT, T., ADAM, S.A., TAIMEN, P., SHIMI, T. and GOLDMAN, R.D. (2010). Nuclear lamins. Cold Spring Harb. Perspect. Biol. 2: a 000547.

DEGRELLE, S.A., BLOMBERG, L.A., GARRETT, W., LI, R. and TALBOT, N. (2009). Comparative proteomics and regulatory network analysis of the elongating pig conceptus. Proteomics 9: 2678-2694.

DEGRELLE, S.A., CAMPION, E., CABAU, C., PIUMI, F., REINAUD, P., RICHARD, C., RENARD J-P. and HUE, I. (2005). Molecular evidence for a critical period in mural trophoblast development in bovine blastocysts. Dev. Biol. 288: 448-460.

DENG, J., ZHAO, C., SPATZ, J.P. and WEI, Q. (2017). Nanopatterned adhesive, stretchable hydrogel to control ligand spacing and regulate cell spreading and migration. ACS Nano 11: 8282-8291.

DUPIN, I., CARMAND, E. and ETIENNE-MANNEVILLE, S. (2009). Classical cadherins control nucleus and centrosome positions and cell polarity. J. Cell Biol. 185: 779-786

DZAMBA, B.J., JOKAB, K.R., MARSDEN, M., SCHWARTZ, M.A., DE SIMONE, D.W. (2009). Cadherin adhesion, tissue tension, and non canonical Wnt signaling regulate fibronectin matrix organization. Dev. Cell 16: 421-432.

EMURA, N., SAKURAI, N., TAKAHASHI, K., HASHIZUME, T. and SAWAY, K. (2016) OCT-4 expression is essential for the sgregation of trophectoderm lineage in porcine preimplantation embryos. J. Reprod. Dev. 62: 401-408.

EYCKMANS, J., BOUDOU, T., YU, X. and CHEN, C.S. (2011). A hitchhicker's guide to mechanobiology. Dev. Cell 21: 35-47.

EZASHI, T., MATSUYAMA, H., TELUGU, B. P. and ROBERTS, R.M. (2011). Generation of colonies of induced trophoblast cells during standard reprogramming of porcine fibroblasts to induced pluripotent cells. Biol. Reprod. 85: 778-787.

FISCHER, E., LEGUE, E., DOYEN, A., NATO, F., NICOLAS, J-F., TORRES, V., YANIV, M. and PONTOGLIO, M. (2005). Defective planar cell polarity in polycystic kidney disease. Nature Genetics 38: 21-23.

FLECHON, J-E. (1991). Three dimensional study of the cytoskeleton of the first differentiated cell types in the porcine blastocyst. In: The living cell in four dimensions. AIP Conference Proceeding 226. 47th Int. Conf. Gif sur Yvette, France, pp. 66-75.

FLECHON, J-E., DEGROUARD, J. and FLECHON, B. (2004 a). Gastrulation events in the prestreak pig embryo: ultrastructure and cell markers. Genesis 38: 13-25.

FLECHON, J-E., DEGROUARD, J., FLECHON, B., LEFEVRE, F. and TRAUB, O. (2004b). Gap junction formation and connexin distribution in pig trophoblast before implantation. Placenta 25: 85-94

FLECHON, J-E., FLECHON, B., DEGROUARD, J. and GUILLOMOT, M. 2007. Cellular features of the extra-embryonic endoderm during elongation of the ovine conceptus. Genesis 45: 709-715.

FLECHON, J-E., GUILLOMOT, M., CARLIER, M., FLECHON, B. and MARTAL, J. (1986). Experimental studies on the elongation of the ewe blastocyst. Reprod. Nutr. Dev. 26: 1017-1024.

FLECHON, J-E., LAURIE, S. and NOTARIANNI, E. (1995). Isolation and characterization of a feeder-dependent, porcine trophectoderm cell line obtained from a 9-day blastocyst. Placenta 16: 643-658.

FLETCHER, D.A. and MULLINS, R.D. (2010). Cell mechanism and the cytoskeleton Nature 463: 485-492.

FOSTER, H.A., STOKES, P., FORSEY, K., LEESE, H.J., BRIDGER, J.M. (2007). Lamins $A$ and $C$ are present in the nuclei of early porcine embryos, with lamin A being distributed in large intranuclear foci. Chromosome Res. 15: 163-174.

FRASER, S.T. and BARON, M.H. (2009) Embryonic fates for extraembryonic lineages: new perspectives. J. Cell Biol. 107: 586-591.

GARROD, I. and CHIDGEY, M. (2008). Desmosome structure, composition and function. Biochem. Biophys. Acta 1778: 572-587.

GEISERT, R.D., BROOKBANK, J.W., ROBERTS, R.M. and BAZER, F.W. (1982). 
Establishment of pregnancy in the pig II. Cellular remodeling of the porcine blastocyst during elongation on day 12 of pregnancy. Biol. Reprod. 27: 941-955.

GEISERT, R.D. and SCHMITT, M. (2015). Early embryonic survival in the pig: can it be improved? J. Anim. Sci. 80 Suppl 1: E54-E65.

GIBSON, W.T., VELDHUIS, J.H., RUBINSTEIN, B., CARTWRIGHT, H.N., PERRIMON, N., BROADLAND, G.W., NAGPAL, R. and GIBSON, M.C. (2011). Control of the mitotic cleavage plane by local epithelial topology. Cell 144: 427-438.

GOPICHANDRAN, N. and LEESE, H.J. (2003). Metabolic characterisation of the bovine blastocyst, inner cell mass, trophectoderm and blastocoel fluid. Reproduction 126: 299-308.

GOOSSENS, K., TESFAYE, D., RINGS, F., SCHELLANDER, K., HOELKER, M., VAN POUCKE, M., VAN ZEVEREN, A., LEMAKIEN, I., VAN SOOM, A. and POELMAN, L.J. (2010). Suppression of Keratin 18 gene expression in bovine blastocysts by RNA Interference. Reprod. Fert. Dev. 22: 395-404

GRUENBAUM, Y. and FOISNER, R. (2015). Lamins: Nuclear intermediate filament proteins with fundamental functions in nuclear mechanisms and genome regulation. Ann. Rev. Biochem. 84: 131-164.

GUENZEL, D. and YU, A.S. (2013). Claudins and the modulation of tight junction permeability. Physiol. Rev. 93: 525-569.

GUILLOT, C. and Lecuit, T. (2013). Mechanism of epithelial tissue homeostasis and morphogenesis. Science 340: 1185-1189.

HAGA, H., IRAHARA, C., KOBAYASHI, R., NAKAGAKI, T., KAWABATA, K. (2005). Collective movement of epithelial cells on a collagen gel substrate. Biophys. J. 88: 2250-2256.

HALACHEVA, V., FUCHS, M., DONITZ, M., REUPKE, T., PUSCHEL, B. and VIEBAHN, C. (2011). Planar cell movements and oriented cell division during early primitive streak formation in the mammalian embryo. Dev. Dyn. 240: 1905-1916.

HAMA, K., AOKI, J., INOUE, A., ENDO, T., AMANO, T., MOTOKI, R., KANAI, M., YE, X., CHUN, J., MATSUKI, N., SUZUKI, H., SHIBASAKI, M., and ARAI, H. (2007). Embryo spacing and implantation timing are differentially regulated by IPA3-mediated lysophosphatidic acid signaling in mice. Biol. Reprod. 77: 954-959.

HANSEN, M.D.H. and KWIATKOWSKI, A.V. (2013). Control of actin dynamics by allosteric regulation of actin binding proteins. Int. Rev. Cell. Mol. Biol. 303: 1-25.

HARNEY, J.P., MIRANDO, M.A., SMITH, L.C. and BAZER, F.W. (1990). Retinol-binding protein: a major secretory product of the pig conceptus. Biol. Reprod. 42: 523-532.

HARSTOCK, A. and NELSON, W.J. (2008). Adherens and tight junctions: structure, function and connections to the actin cytoskeleton. Biochim. Biophys. Acta 1778: 660-669.

HASSOUN, R., SCHWARTZ, P., FEISTEL, K., BLUM, M. and VIEBAHN, C. (2009). Axial differentiation and early gastrulation stages of the pig embryo. Differentiation 78: 301-311.

HAWKINS, T., MIRIGIAN, M., YASAR, M.S. and ROSS, J.L. (2010). Mechanics of Microtubules. J. Biomechanics 43: 23-30.

HERSZTERG, S., PINHIERO, D., BELLAICHE, Y. (2014). A multicellular view of cytokinesis in epithelial tissue. Trends Cell Biol. 24: 285-293.

HOGAN, B.L.M. and TILLY, R. (1981). Cell interactions and endoderm differentiation in cultured mouse embryos. J. Embryol. Exp. Morphol. 62: 379-394.

HOU, D., SU, M., LI, X., LI, Z., YUN, T., ZHANG, M., ZAO, L., LI, R., YU, H. and LI, $X$. (2015). The efficient derivation of trophoblast cells from porcine in vitro fertilized and parthenogenetic blastocysts and culture with ROCK inhibitor Y-27632. PLoS One 10: eO 142442.

HUBRECHT, A.A.W. (1889). Studies in mammalian embryology. I. The placentation of Erinaceus europaeus, with remarks on the philogeny of the placenta. Q. J. Microsc. Soc. 30: 283-404.

HUE, I., EVAIN-BRION, D., FOURNIER, T. and DEGRELLE, S. (2015). Primary bovine extra-embryonic cultured cells: a new resource for the study of in vivo peri-implantation phenotypes and mesoderm formation. PLOS One DOI 10-1371.

INMAN, J.L. and BISSELL, M. (2010). Apical polarity in three-dimensional culture systems: where to now? J. Biol. 9: 2.

ISHRATSCH, T., WOLFSON, H. and SHEETZ, M. (2014). Appreciating force and shape - the rise of mechano -transduction in cell biology. Nature Rev. Mol. Cell Biol. 15: 825-833.

IVANOV, A.I. and NAYDENOV, N.G. (2013). Dynamics and regulation of epithelial adherens junctions: recent discoveries and controversies. Int. Rev. Cell. Mol. Biol. 303: 27-99.
JANG, H., CHOI, Y., YOO, I., HAN, J., KIM, M. and KA, H. (2017). Characterization of interferon alpha and beta receptor IFNAR1 and IFNAR2 expression and regulation in the uterine endometrium during the oestrous cycle and pregnancy in pigs. Theriogenology 88: 166-173.

JENSEN, P.L., GRøNDAHL, M.L., BECK, H.C., PETERSEN, J., STROEBECH, L., CHRISTENSEN, S.T. and ANDERSEN, C.Y. (2014). Proteomic analysis of bovine blastocoel fluid and blastocyst cells. Syst. Biol. Reprod. Med. 60: 127-135.

JEONG, W., SEO, H., SUNG, Y., KA, H., SONG, G. and KIM, J. (2016). Lysophosphatidic acid (LPA) receptor 3-mediated LPA signal transduction pathways: a possible relationship with early development of peri-implantation porcine conceptus. Biol. Reprod. 94: 1-11.

JOHNSON, G.A., BURGHARDT, R.C. and BAZER, F.W. (2014). Osteopontin: a leading candidate adhesion molecule for implantation in pigs and sheep. J. Anim. Sci. Biotechnol. 5: 56

JOYCE, M.M., BURGHARDT, J.R., HOOPER, R.N., BAZER, F.W. and JOHNSON, G.A. (2008). Uterine major histocompatibily class I molecules and beta-2 microglobulinare regulated by progesterone and conceptus interferons during pig pregnancy. J. Immumol. 181: 2494-2505.

KHATAU, S.B., HALE, C.M., STEWART-HUTCHINSON, P.J., PATEL, M.S., STEWART, C.L., SEARSON, P.C., HODZIC, D. and WIRTZ, D. (2009). A perinuclear actin cap regulates nuclear shape. Proc. Nat. Acad. Sci. USA 106: 1917-1922.

KEYS, J.L. and KING, G.J. (1990). Microscopic examination of porcine conceptusmaternal interface between days 10 and 19 of pregnancy. Dev. Dyn. 188:221-238.

KIM, J., ERICKSON, D.W., BURGHARDT, R.C., SPENCER, T.E., WU, G., BAYLESS, K.J., JOHNSON, G. A. and BAZER, F.W. (2010). Secreted phosphoprotein 1 binds integrins to initiate multiple cell signaling pathways, including FRAP1/mTOR, to support attachment and force-generated migration of trophectoderm cells. Matrix Biol. 29: 369-382.

KIM, S-H., TURNBULL, J., GUIMOND, S. (2011). Extracellular matrix and cell signalling: the dynamic cooperation of integrin, proteoglycan and growth factor receptor. J. Endocrinol. 209: 139-151.

KIRSCHHOF, N., CARNWATH, J.W., LEMME, E., ANASTASIADIS, K., SCHOELER, H. and NIEMAN, H. (2000). Epression pattern of OCT-4 in preimplantation embryos of different species. Biol. Reprod. 63: 1698-1705.

KRAWCZYNSKI, K., NAJMULA, J., BAUERSACHS, S. and KACZMAREK, M.M. (2015). MicroRNAome of porcine conceptus and trophoblasts: expression profile of microRNAs and their potential to regulate genes crucial for establishment of pregnancy. Biol. Reprod. 92: 21, 1-13.

KRUPINSKI, P., CHIKARMANE, V. and PETERSON, C. (2011). Simulating the mammalian blastocyst - molecular and mechanical interactions pattern the embryo. PLoS Comput. Biol. 7: e1001128.

KUIJK, E.W., Du PUY, L., Van TOL, H.T.A., OEI, C.H.Y., HAAGSMAN, H.P., COLENBRANDER, B. and ROELEN, B. A. J. (2008). Differences in early lineage segregation between mammals. Dev. Dyn. 237: 918-927.

KWON, G.S., VIOTTI, M., HADJANTONAKIS, A.K. (2008). The endoderm of the mouse embryo arises by dynamic widespread intercalation of embryonic and extraembryonic lineages. Dev. Cell 15: 509-520.

LA BONNARDIERE, C., FLECHON, J-E., BATTEGAY, B., FLECHON, B., DEGROUARD, J. and LEFEVRE, F. (2002). Polarized porcine trophoblastic cell lines spontaneously secrete interferon-gamma. Placenta 23: 716-725.

LANDSVERK, M.L. and EPSTEIN, H.F. (2005). Genetic analysis of myosin II assembly and organization in model organisms. Cell. Mol. Life Sci. 62: 2270-2282.

LECUIT, T., LENNE, P-F. and MUNRO, E. (2011). Force generation, Transmission, and integration during cell and tissue morphogenesis. Ann. Rev. Cell Dev. Biol. 27: 157-184.

LEE, K., FODOR, W.L. and MACHATY, Z. (2007). Dynamics of lamin A/C in porcine embryos produced by nuclear transfer. Mol. Reprod. Dev. 74: 1221-1227.

LEISS, M., BECKMANN, K., GIROS, A., COSTELL, M. and FAESSLER, R. (2008). The role of integrin binding sites in fibronectin matrix assembly in vivo. Curr. Opin. Cell Biol. 20: 502-507.

LELIEVRE, S.A., WEAVER, V.M., NIEKERSON, J.A., LARABELL, C.A., BHAUMIK A., PETERSEN, O.W. and BISSEL, M.J. (1998). Tissue morphogenesis depends on reciprocal interactions between the extracellular matrix and the structural organization of the nucleus. Proc. Nat. Acad. Sci. USA 95: 14711-14716.

LEMAITRE, C. and BICKMORE, W.A. (2015). Attachment of chromatin to the nuclear periphery. Histochem. Cell Biol. 144: 111-122. 
LI, Z., LEE, H. and ZHU, C. (2016). Molecular mechanisms of mechanotransduction in integrin-mediated cell-matrix adhesion. Exp. Cell Res. 349: 85-94.

LOGANATHAN, R., RONGISH, B.J., SMITH, C.M., FILLA, M.B., CZIROK, A., BENAZERAF, B. and LITTLE, C.D. (2016). Extracellular matrix motion and early morphogenesis. Development 143: 2056-2065.

LOZZO, R.V. and SCHAEFFER, L. (2015). Proteoglycan form and function: a comprehensive nomenclature of proteoglycans. Matrix Biol. 42: 14711-14716

LUBARSKY, B. and KRASNOV, M.A. (2003). Tube morphogenesis: making and shaping biological tubes. Cell 112: 19-28.

MAMMOTO, A., MAMMOTO, T. and INGBER, D.E. (2012). Mechanosensitive mechanisms in transcriptional regulation. J. Cell Sci. 125: 3061-3073.

MARCOS, J., PEREZ-ALBALA, S., MIFSUD, A., MOLLA, M., LANDERAS, J. and MESEGUER, M. (2015), Collapse of blastoctsts is strongly related to lower implantation success: a time-lapse study. Human Reprod. 30: 2501-2508

MARIKAWA, Y. and ALARCON, V.B. (2012). Creation of trophectoderm: the first epithelium, in mouse preimplantation development. Results Probl. Cell Diff. 55: 165-184.

MATSUDA, M., KUBO, A., FURUSE, M., and TSUKITA, S. (2004). A peculiar internalization of claudins, tight junction-specific adhesion molecules, during the intercellular movement of epithelial cells. J. Cell Sci. 117: 1247-1257

MATTER, L. and BALDA, M.S. (2007). Epithelial tight junctions, gene expression and nucleo-junctional interplay. J. Cell Sci. 120: 1505-1511.

MATTSON, B.A., OVERSTROM, E.W. and ALBERTINI, D.F. (1990). Transitions in trophectoderm cellular shape and cytoskeletal organization in the elongating pig blastocyst. Biol. Reprod. 42: 195-205.

MUNJAL, A., PHILIPPE, J.M., MUNRO, E. and LECUIT, T. (2015). A self organized biochemical network drives shape changes during tissue morphogenesis. Nature 254: 351-355.

NIMURA, S. and SATO, J. (2009). A physiological role of contractions in hatched blastocysts. Reprod. Med. Biol. 8: 53-58.

NOTARIANNI, E. and HIRST, B.H. (1999). Electrogenic sodium transport mediated by an amiloride-sensitive conductance in a porcine trophectoderm cell line. Placenta 20: 149-154.

OHASHI, T., KICHART, D.F. and ERICKSON, H.P. (1999). Dynamics and elasticity of the fibronectin matrix in living cell culture vizualized by fibronectin-green fluorescent protein. Proc. Nat. Acad. Sci. USA 96: 2153-2158.

PANKOV, R. and YAMADA, K.M. (2002). Fibronectin at a glance. J. Cell Sci. 115: 3861-3863.

PAPAIOANIOU, V.E. and EBERT, K.M. (1988). The preimplantation pig embryo: cell number and allocation to trophectoderm and inner cell mass of the blastocyst in vivo and in vitro. Development 102: 793-803.

PARROW, V., HORTON, C., MADEN, M., LAURIE, S. and NOTARIANNI, E. (1998). Retinoids are endogenous to the porcine blastocyst and secreted by trophectoderm cells at functionally active levels. Int. J. Dev. Biol. 42: 629-632.

PERRY, J.S. (1981). The mammalian fetal membrane. J. Reprod. Fertil. 62: 321-335.

PLACHOT, C., CHABOUB, L.S., ADISSU, H.A., WANG, L., URAZAEV, A., STURGIS, J.,ASEM, E.K. and LELIEVRE, S. (2009). Factors necessary to produce basoapical polarity in human glandular epithelium formed in conventional and high-throughput three-dimentional culture: example of the breast epithelium. BMC Biol. 7: 77.

POESCHL, E., SCHLOETZER-SCHREHARDT, U., BRACHVOGEL, B., SAITO, K., NINOMIYA, Y. and MAYER, U. (2004). Collagen IV is essential for basement membrane stability, but dispensable for initiation of its assembly during early development. Development 131: 1619-1628.

POLI, M., ORI, A., CHILD, T., JAROUDI, S., SPATH, K., BECK, M. and WELLS, D. (2015). Characterization and quantification of proteins secreted by single human embryos. EMBO Mol. Med. 7: 1465-1479.

RANDOW, F. and SEED, B. (2001). Endoplasmic reticulum chaperone gp96 is required for innate immunity but not cell Viability. Nature Cell Biol. 3: 891-896.

REIMA, I., LEHTONEN, E., VIRTANEN, I. and FLECHON, J-E. (1993). The cytoskeleton and associated proteins during cleavage, compaction and blastocyst differentiation in the pig. Differentiation 54: 35-45.

REINSCH, S. and KAESENTI, E. (1994). Orientation of spindle axis and distribution of plasma membrane proteins during cell division in polarized MDCK II cells. $J$. Cell Biol. 126: 1509-1526.

RICHOUX, V., DARRIBERE, T., BOUCAUT, J.C., FLECHON, J-E. and THIERY, J-P. (1989). Distribution of fibronectins and laminin in the early pig embryo. Anat.
Rec. 223: 72-81

ROBERTS, R.M., Xie, S. and Trout, W.E. (1993). Embryo-uterine interactions in pigs during week 2 of pregnancy. J. Reprod. Fertil. Suppl. 48: 171-186.

SANDRA, O., CHARPIGNY, G., GALIO, L. and HUE, I. (2017). Preattachmentembryos of domestic animals: insights into development and paracrine secretions. Annu. Rev. Anim. Biosci. 5: 18.1-18.24.

SATO, K., HIRAIWA, T. and SHIBATA, T. (2015). Cell chirality induces collective cell migration in epithelial sheets. Phys. Rev. Lett. 115: 188102.

SCHILPEROORT-HAUN, K.R. and MENINO, A.R. Jr (2002). Factors affecting cellular outgrowth from porcine inner cell mass in vitro. J. Anim. Sci. 80: 2671-2681.

SCHWARTZ, M.A. (2010). Integrins and extracellular matrix in mechanotranscription. Cold Spring Harb. Perspect. Biol. 2010, 2: a005066.

SHEHU, D., MARSICANO, G., FLECHON, J-E. and GALLI, C. (1996). Developmentally regulated markers of in vitro-produced preimplantation bovine embryos. Zygote 4: 109-121.

SHENG, G. (2015). Epiblast morphogenesis before gastrulation. Dev. Biol. 401:17-24.

SHINK, K., FOG, V.C. and MARGOLIS, B. (2006). Tight junctions and cell polarity. Ann. Rev. Cell Dev. Biol. 22: 207-235.

SKOGLUND, P., ROLO, A., CHEN, X., GUMBINER, B.M. and KELLER, R. (2008). Convergence and extensionat gastrulation require a myosin IIB -dependent cortical actin network. Development 135: 2435-2444.

SOLAN, A., DAHL, S.L. and NIKLASON, L.E. (2009).Effects of mechanical stretch on collagen and cross-linking in engineered blood vessels. Cell Transplant. 18 915-921.

STEPHENSON, R.O., YAMANAKA, Y. and ROSSANT, J. (2010). Disorganized epiblast polarity and excess trophectoderm cell fate in preimplantation embryos lacking E-cadherin. Development 137: 3383-3391.

STERN, C. and DOWNS, K.M. (2012). The hypoblast (visceral endoderm): An evodevo perspective. Development 139:1059-1069.

TADA, M. and HEISENBERG, C-P., (2012). Convergent extension: using collective cell migration and cell intercallation to shape embryos. Development 139: 3897-3904.

TALBOT, N.C., BLOMBERG, L.A., MAHMOOD, A., CAPERNA, T.J. and GARRETT, W.M. (2007). Isolation and characterization of porcine visceral endoderm cell lines derived from in vivo 11-day blastocysts. In Vitro Cell Dev. Biol. Animal 43: 72-86.

TALBOT, N.C. and CAPERNA, T.J. (2015). Proteome array identification of bioactive soluble proteins/peptides in Matrigel: relevanceto stem cell responses. Cytotechnology 67: 873-883.

TANG, N. and MARSHALL, W.F. (2012). Centrosome positioning in vertebrate development. J. Cell Sci. 125: 4951-4961.

THERY, M., RACINE, V., PEPIN, A., PIEL, A., CHEN, Y., SIBARITA, J.B. and BORNENS, M. (2005). The extracellular matrix guides the orientation of the cell division axis. Nature Cell Biol. 10: 947-953.

TIAN, X., LIU, Z., NIU, B., TAN, T.K., LEE, S.R., ZHAU, Y., HARRIS, D.C.H. and ZHENG, G. (2011). E-cadherin/Beta-catenin complex and the epithelial barrier. J. Biomed. Biotechnol. 2011: 567305.

TROUT, W.E., MCDONNELL, J.J., KRAMER K.K., BAUMBACH, G.A. and ROBERTS R.M. (1991). The retinol-binding protein of the expanding pig blastocyst. Molec. Endocrinol. 5: 1533-1540.

TURUNEN, O., WINQVIST, R., PAKKANEN, R., GRZESCHIK, K.H., WAHLSTROM, T. and VAHERI, A. (1989). Cytovillin, a Microvillar Mr 75,000 protein. CDNA sequence, prokariotic expression, and chromosomal localization. J. Biol. Chem. 264: $16,727-16,732$

VANITALLIE, C.M., FANNING, A.S., BRIDGES, A. and ANDERSON, J.A. (2009). ZO-1 stabilizes the tight junction solute barrier through coupling to the perijunctional cytoskeleton. Mol. Biol. Cell 20: 3930-3940.

VAN LEEUWEN, J., BERG, D.K. and PFEFFER, P.L. (2015). Morphological and gene expression changes in cattle embryos from hatched blastocyst to early gastrulation stages after transfer of in vitro produced embryos. PLoS One 10: e0129787.

VEJLSTED, M., DU, Y., VAJTA, G., MADDOX-HYTTEL, P. (2006). Post-hatching development of the porcine and bovine embryo--defining criteria for expected development in vivo and in vitro. Theriogenology 65: 152-165.

VIGNAUD, T., BLANCHOIN, L. and THERY, M. (2012). Directed cytoskeleton selforganization. Trends Cell Biol. 22: 671-682.

WALLINGFORD, J.B., FRASER, S.E. and HARLAND, R.M. (2003). Convergent 
extension: the molecular control of polarized cell movement during embryonic development. Dev. Cell 2: 695-706.

WANG, J., GUILLOMOT, M. and HUE, I. (2009). Organisation cellulaire des cellules trophoblastiqes dans l'élongation du conceptus ovin. C.R. Acad. Sci. Paris Biologies 332: 986-997.

WHYTE, A., BACON, M. and ELLIS, S. (1984). A monoclonal antibody to an antigen present on the microvillous membrane of the trophectoderm of the preimplantation blastocyst of the pig. J. Reprod. Fertil. 71: 599-605.

WINDORFFER, R., BORCHERT-STUHLTRAEGER, M. and LEUBE, R.E. (2002). Desmosomes: interconnected calcium-dependent structures of remarquable stability with significant integral membrane protein turnover. J. Cell Sci. 115: 1717-1732.

WINTENBERGER-TORRES, S. and FLECHON, J-E. (1974). Ultrastructural evolution of the trophoblast cells of the preimplantation sheep blastocyst from day 8 to day 18. J. Anat. 118: 143-153.

WOLFENSON, H., BERSHADSKY, A., HENIS, Y.I. and GEIGER, B. (2011). Actomyosin-generated tension controls the molecular kinetics of focal adhesions. $J$. Cell Biol. 124: 1425-1432.

XU, S., LEE, J. and MIYAKE, M. (2012). Expression of ZO-1 and occludin at mRNA and protein level during preimplantation development of the pig parthenogenetic diploids. Zygote 20: 147-158.

YAMADA, M. and SEKIGUCHI, K. (2015). Molecular basis of laminin-integrin interactions. Curr. Top. Membr. 76: 197-229.

YAP, A.S., CRAMPTON, M.S. and HARDIN, J. (2007). Making and breeking contacts: the cellular biology of cadherin regulation. Curr. Opin. Cell Biol. 19: 508-51.

YE, X. and CHUN, J. (2010). Lysophosphatidic acid (LPA) signaling in vertebrate reproduction. Trends Endocrinol. Metab. 21: 17-24.

YONEMURA, S. (2011).Cadherin-catenin interactions at adherens cell junctions. Curr. Opin. Cell Biol. 23: 515-522.

YOSHINAGA, K. (2013). A sequence of events in the uterus prior to implantation in the mouse. J. Assist. Reprod. Genet. 30: 1017-1022.

ZHANG, H., HUANG, Y., WANG, L., YU, T., WANG, Z., CHANG, L., ZHAO, X., LUO, X., ZHANG, L. and TONG, D. (2016). Immortalization of porcine placental trophoblast cells through reconstitution of telomerase activity. Theriogenology 85: 1446-1456.

ZIEGLER, W.H., LIDDINGTON, R.C. and CRITCHLEY, D.R. (2006). The structure and regulation of vinculin. Trends Cell Biol. 16: 453-460. 


\section{Further Related Reading, published previously in the Int. J. Dev. Biol.}

Cell signaling in trophoblast-uterine communication

Rani Fritz, Chandni Jain and D. Randall Armant

Int. J. Dev. Biol. (2014) 58: 261-271

https://doi.org/10.1387/ijdb.140011da

BMP4 regulation of human trophoblast development

Yingchun Li and Mana M. Parast

Int. J. Dev. Biol. (2014) 58: 239-246

https://doi.org/10.1387/ijdb.130341mp

DNA methylation and its role in the trophoblast cell lineage

Satoshi Tanaka, Momo O. Nakanishi and Kunio Shiota

Int. J. Dev. Biol. (2014) 58: 231-238

https://doi.org/10.1387/ijdb.140053st

Developmental cell biology of human villous trophoblast: current research problems John D. Aplin

Int. J. Dev. Biol. (2010) 54: 323-329

https://doi.org/10.1387/ijdb.082759ja

Development and function of trophoblast giant cells in the rodent placenta

Dong $\mathrm{Hu}$ and James C. Cross

Int. J. Dev. Biol. (2010) 54: 341-354

https://doi.org/10.1387/ijdb.082768dh

Placentation in mammals once grouped as insectivores

Anthony M. Carter and Allen C. Enders

Int. J. Dev. Biol. (2010) 54: 483-493

https://doi.org/10.1387/ijdb.082830ac

Trophoblast phagocytic program: roles in different placental systems

Estela Bevilacqua, Mara-Sandra Hoshida, Andrea Amarante-Paffaro, Andrea Albieri-Borges and Sara Zago-Gomes

Int. J. Dev. Biol. (2010) 54: 495-505

https://doi.org/10.1387/ijdb.082761eb

5 yr ISI Impact Factor $(2013)=2.879$
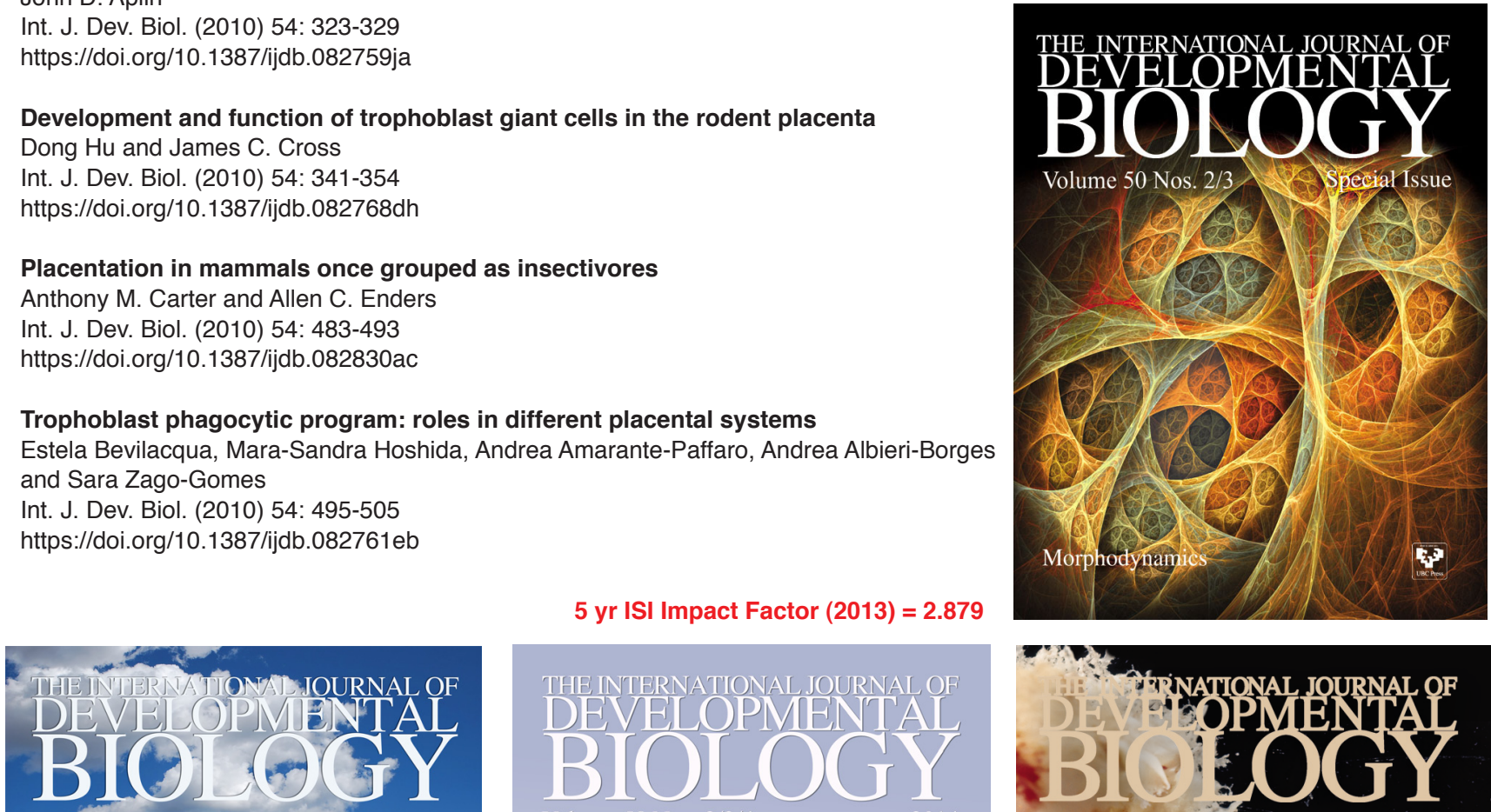

Volume 56 Nos. 10/11/12 - Special Issue
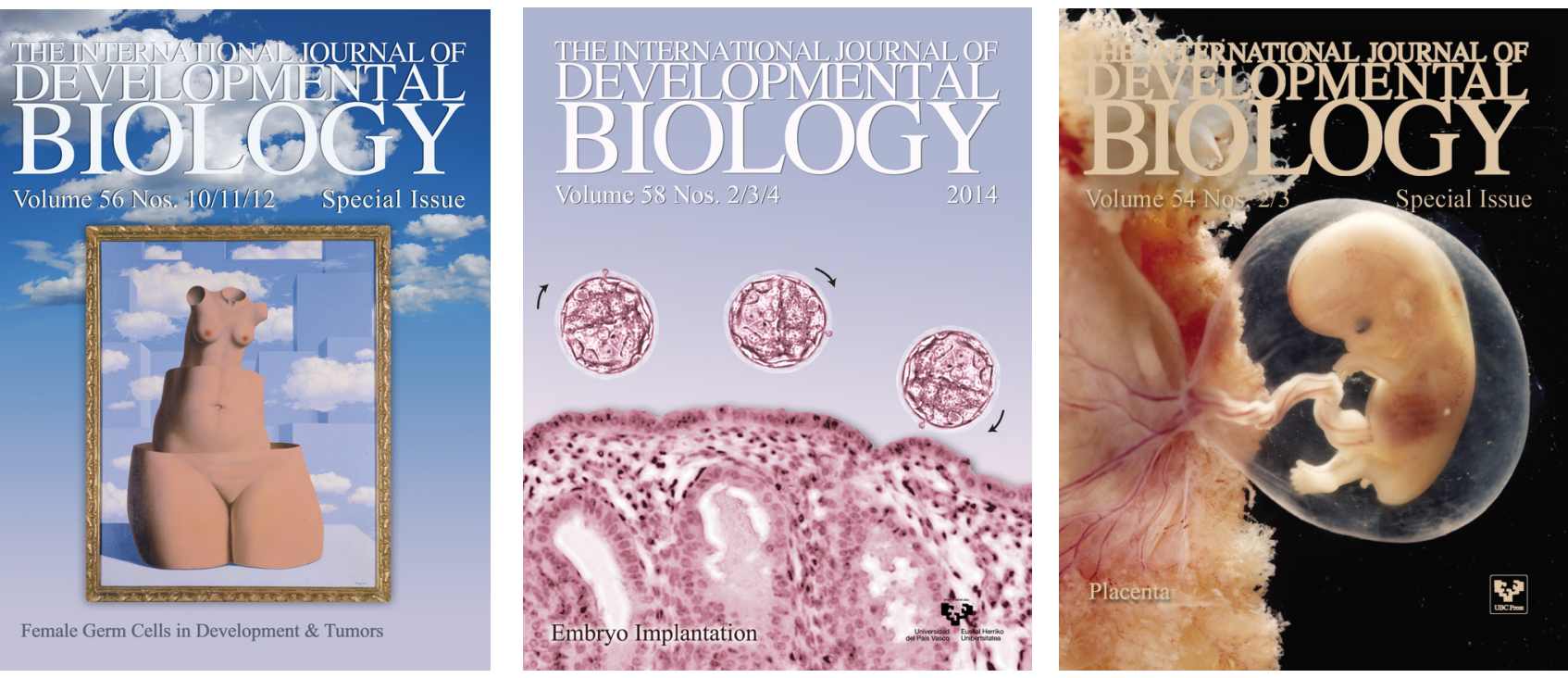